Review

\title{
Functional Nutrients for Epilepsy
}

\author{
Ji-Eun Kim and Kyung-Ok Cho * \\ Department of Pharmacology, Department of Biomedicine \& Health Sciences, Catholic Neuroscience Institute, \\ Institute of Aging and Metabolic Diseases, College of Medicine, The Catholic University of Korea, \\ Seoul 06591, Korea; jonin12@naver.com \\ * Correspondence: kocho@catholic.ac.kr; Tel.: +82-2-2258-7329; Fax: +82-2-536-2485
}

Received: 30 April 2019; Accepted: 6 June 2019; Published: 10 June 2019

\begin{abstract}
Epilepsy is a common neurological disorder of which seizures are a core symptom. Approximately one third of epileptic patients are resistant to antiepileptic drugs and therefore require alternative therapeutic options. Dietary and nutritional supplements can in some cases replace drugs, but with the exception of ketogenic diets, there are no officially recommended dietary considerations for patients with epilepsy. In this review we summarize a selection of nutritional suggestions that have proved beneficial in treating different types of epilepsy. We describe the types of seizures and epilepsy and follow this with an introduction to basic molecular mechanisms. We then examine several functional nutrients for which there is clinical evidence of therapeutic efficacy in reducing seizures or epilepsy-associated sudden death. We also discuss experimental results that demonstrate possible molecular mechanisms elicited by the administration of various nutrients. The availability of multiple dietary and nutritional candidates that show favorable outcomes in animals implies that assessing the clinical potential of these substances will improve translational medicine, ultimately benefitting epilepsy patients.
\end{abstract}

Keywords: epilepsy; seizure; nutrients; omega-3 fatty acid; vitamin D3; vitamin E; vitamin B6

\section{Introduction}

Epilepsy is a common neurological disease with a prevalence of approximately 0.4 to $1 \%$ which affects people of all ages and races, and both genders [1]. It is a heterogeneous group of disorders with a variety of etiologic backgrounds associated with seizure manifestation [2]. Germline or somatic mutations; structural brain lesions including stroke, cancer, trauma, and status epilepticus; various infections; metabolic defects; and autoimmune-mediated dysregulation of inflammation can all elicit seizures, which range from altered sensation of the five senses to rapid head and eye movement to brief or prolonged loss of consciousness to uncontrolled muscle contractions and spasms [1,3]. Vigorous efforts to delineate different types of epilepsy in a more precise manner and to treat patients using antiepileptic drugs with appropriate mechanisms of action have made great progress in suppressing unexpected seizures. Some $70 \%$ of epilepsy patients now exercise seizure management [1]. However, for the remaining 30\%, who suffer from intractable epilepsy, treatment options are limited to different multi-drug therapies or surgery if applicable. Alternative treatments for patients with refractory epilepsy are therefore needed. 
Functional foods and bioactive nutrients can be considered part of adjunctive therapy or an essential strategy for the treatment of epilepsy, depending on the etiologic nature [4-19]. For certain metabolic epilepsies, supplying deficient nutrients can correct inborn errors and stop seizures [20], while for most refractory epilepsies, no obvious effective dietary recommendations are available other than ketogenic diets [21,22]. To provide comprehensive information about nutritional supplements for the treatment of epilepsy, we summarize here functional nutrients that have shown therapeutic efficacy in drug-refractory epilepsy. First, we provide an overview of epilepsy and its essential molecular mechanisms. We then summarize a selection of biologically active nutrients that can be used as add-on or first-line therapy for intractable epilepsies, based on PubMed search criteria with combinations of keywords including "nutrient", "functional food", "nutrition", "nutritional", "dietary supplement", "supplementation", "vitamin", "mineral", "fatty acids", “epilepsy", “epilepsy syndrome”, "refractory epilepsy", "intractable epilepsy", "drug-resistant epilepsy", "temporal lobe epilepsy", "genetic generalized epilepsy", and "metabolic epilepsy", etc. Finally, we discuss the experimental evidence supporting the clinical findings.

\section{General Overview of Epilepsy}

\subsection{Classification of Seizures}

A variety of factors can elicit the transient, synchronous, and excessive neuronal activities that cause seizures. Because current knowledge is not yet sufficient to distinguish between various types of seizures based on etiology, seizures are classified by their mode of onset, degree of awareness, and initial symptoms. In the latest classification released by the International League Against Epilepsy (ILAE) in 2017 (Figure 1), seizure types are divided into three groups: focal onset, generalized onset, and unknown onset [23]. Focal and generalized seizures are classified by where and how seizure activity begins. For example, focal onset seizures are localized in discrete areas of the brain, usually in one hemisphere, whereas generalized onset seizures immediately engage bilaterally-distributed networks of the brain. For focal seizures, the level of awareness can be further described to display seizure characteristics, in addition to the first prominent sign such as motor symptoms (automatisms, atonic, clonic, epileptic spasms, hyperkinetic, myoclonic, tonic) or non-motor symptoms (autonomic, behavior arrest, cognitive, emotional, sensory). Finally, focal to bilateral tonic-clonic seizures are categorized as focal seizures when an initial seizure focus is identifiable. Generalized onset seizures can be divided into motor or non-motor (absence) seizures. Depending on the clinical diagnostic observations, motor seizures can be further classified as tonic-clonic, clonic, tonic, myoclonic, myoclonic-tonic-clonic, myoclonic-atonic, atonic, and epileptic spasms, while non-motor seizures can be categorized as typical, atypical, myoclonic, and eyelid myoclonia. Seizures of unknown onset can be described as "unclassified" or with additional characteristics such as motor (tonic-clonic or epileptic spasms) or non-motor (behavior arrest) symptoms. However, if seizure onset can be determined at a later time, seizures of unknown onset can be re-categorized as either focal or generalized seizures. 


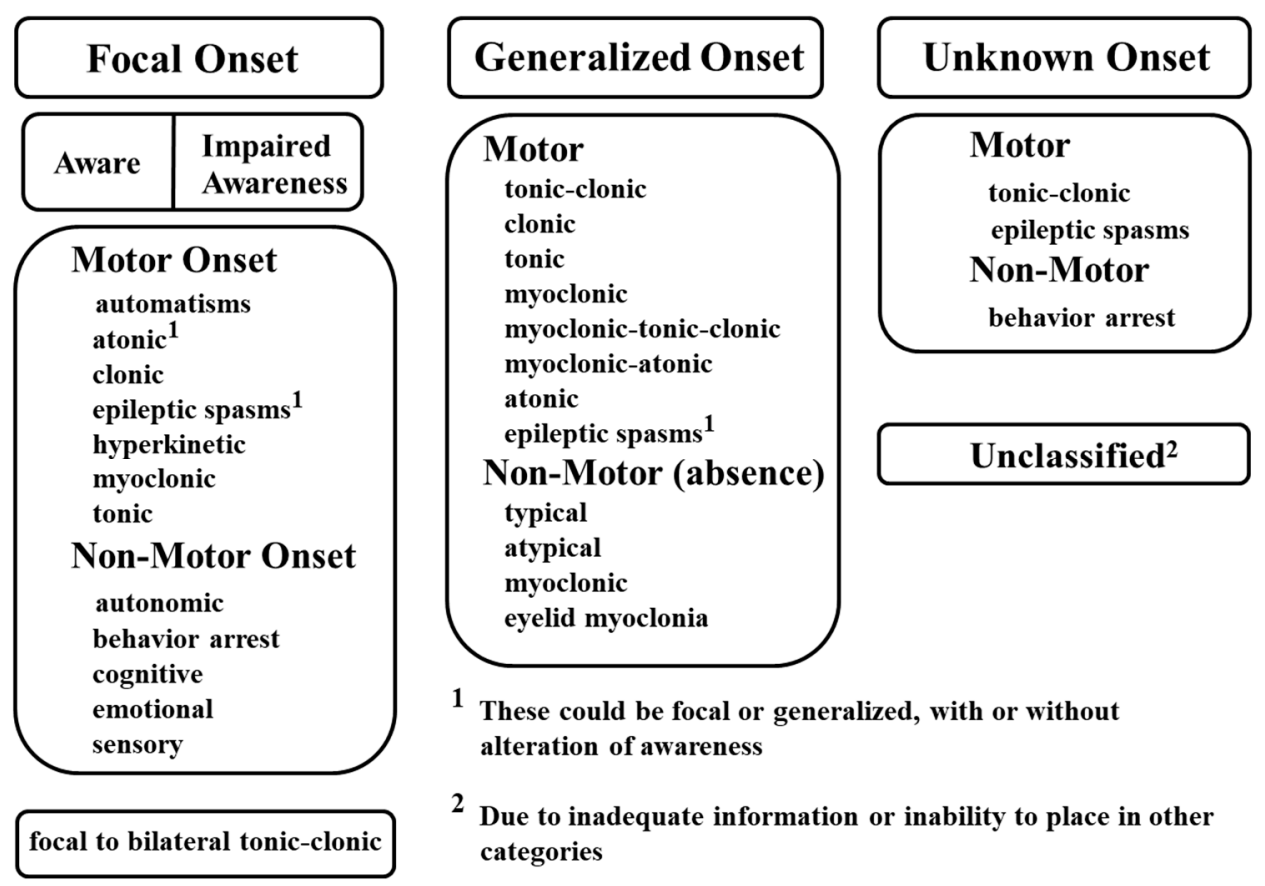

Figure 1. International League Against Epilepsy (ILAE) guidelines for the classification of seizure types. Reprinted with permission from Wiley [23].

\subsection{Classification of Epilepsy}

Epilepsy has been defined as the experience of at least two unprovoked seizures more than $24 \mathrm{~h}$ apart. However, ILAE has revised the definition of epilepsy, providing wider diagnostic criteria that include additional conditions: (1) one unprovoked seizure and a $60 \%$ or greater probability of further seizures occurring over the next 10 years, which is similar to the general recurrence risk after two unprovoked seizures; (2) a diagnosis of epilepsy syndrome [2]. As epilepsy includes heterogeneous encephalopathies sharing a common symptom, namely, seizures, continuous efforts to categorize epilepsies based on their characteristics have been made [3,24]. The revised classification proposes three levels of diagnostic steps with an additional two factors (Figure 2) [3]. The first level involves determining seizure types that have been described in the previous section. Once the seizure types can be classified with clinical tools, such as an electroencephalogram (EEG) and proper imaging modalities, the epilepsy types can be further determined. The four groupings for the second level classification of epilepsies are focal, generalized, combined generalized and focal, and unknown. Focal epilepsies generally show abnormal EEG activity in one hemisphere, whereas generalized epilepsies show generalized spike-wave activity in both hemispheres. However, epilepsy can include multiple types of seizures. For instance, generalized epilepsy can manifest as tonic-clonic seizures and myoclonic jerks. The third diagnostic level involves evaluating whether a patient's epilepsy can be recognized as a distinctive clinical disorder, i.e., epilepsy syndrome. Although there is no official ILAE list of epilepsy syndromes, Ohtahara syndrome, early myoclonic encephalopathy, West syndrome, Dravet syndrome, Lennox-Gastraut syndrome, Lindau-Kleffner syndrome, childhood absence epilepsy, juvenile absence epilepsy, juvenile myoclonic epilepsy, generalized tonic-clonic seizures alone, Rasmussen syndrome, Sturge-Weber syndrome, mesial temporal lobe epilepsy (TLE) with hippocampal sclerosis, self-limited epilepsy with centrotemporal spikes, self-limited occipital epilepsies of childhood, and Panayiotopoulos syndrome can be included within epilepsy syndrome, and are differentially classified based on the age of onset, seizure triggers, and diurnal variation, together with EEG and imaging findings. 


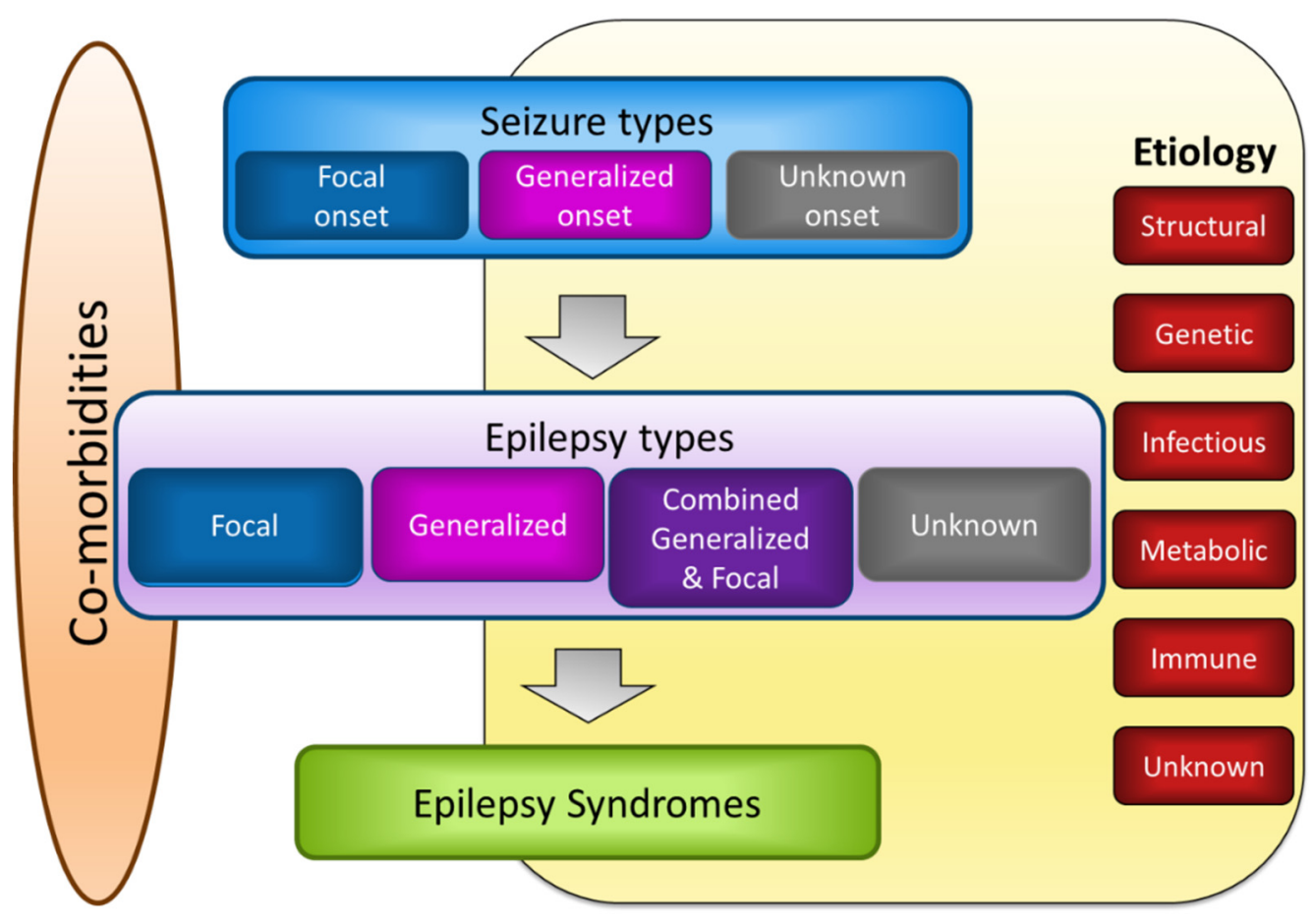

Figure 2. ILAE guidelines for the classification of epilepsies. Reprinted with permission from Wiley [3].

The type of epilepsy can be further specified by etiological implication, which can be of structural, genetic, infectious, metabolic, immune, or unknown etiology. Structural abnormalities such as stroke-induced infarction, trauma, hippocampal sclerosis, and hypothalamic hamartoma are associated with an increased risk of being epileptic. Brain lesions visualized by imaging tools can also identify candidate surgical areas for the treatment of acquired epilepsy. As basic epilepsy research and genetic screening techniques have improved more than 400 genetic mutations associated with epilepsy have been identified, including SCN1A, SCN2A, SCN3A, SCN8A, SCN9A, SCN1B, KCNQ2, KCNQ3, KCTD7, CACNA1H, CLCN2, GABRA1, GABRB3, GABRG2, SLC2A1, CDKL5, ARX, CHD2, STXBP1, and PNPO [25-27]. "Genetic" does not mean "inherited," as both germline and de novo mutations can cause epilepsy. Diverse infectious organisms can cause epilepsy, and these forms are different from seizures originating from simple acute meningitis or encephalitis. Examples include neurocysticercosis, tuberculosis, human immunodeficiency virus (HIV), cerebral malaria, cerebral toxoplasmosis, and congenital Zika or cytomegalovirus infections. Metabolic epilepsy refers to metabolic diseases that manifest unprovoked seizures. Most metabolic epilepsies, such as porphyria, uremia, aminoacidopathies, and pyridoxine deficiency, have a genetic basis, but acquired metabolic epilepsy, i.e., cerebral folate deficiency, also exists. Epilepsies with immunological backgrounds have increased due to the advancement of immunological tests that utilize numerous antibodies. Such epilepsies are essentially variants of autoimmune encephalitis, including anti-N-methyl-D-aspartate (NMDA)-receptor encephalitis or anti-leucine-rich glioma-inactivated-1 (LGI1) encephalitis, in which autoantibodies for autoantigens elicit excessive inflammation in the brain.

The final diagnostic step is the consideration of comorbidities associated with epilepsy. Frequently listed abnormalities include learning and memory impairment, mood disturbance, autism spectrum disorders, and psychosocial issues. However, as epilepsies cover a range of seizure-related disorders, more severe comorbidities that can cause permanent sequelae such as cerebral palsy, gait disturbance, or developmental delay can also be observed. Accurate categorization will therefore be essential for the comprehensive treatment and better understanding of the complex nature of epilepsy. 


\section{Molecular Mechanisms of Epilepsy}

An imbalance between excitation and inhibition has long been thought to be one of the main mechanisms that cause spontaneous seizures, based on the classical channelopathy model of epilepsy [27,28]. Single-nucleotide mutations such as missense, frameshift and nonsense mutations, copy number variations by de novo or inherited DNA deletion or duplication, and chromosomal copy number abnormalities can cause genetic epilepsies [29]. However, acquired epilepsy (i.e., TLE) can develop from the initial insult and subsequent accumulation of multiple structural changes that promote network excitabilities, ultimately ending in spontaneous recurrent seizures [28]. In addition, rapid technological advancements in gene panel screening and next-generation sequencing for both genetic and acquired epilepsies have identified several new molecular candidates that do not appear to have a direct link with network hyperexcitability $[25,29,30]$. Emerging evidence suggests that the pathophysiological mechanisms of epilepsy are much more complicated than expected, prompting demand for more vigorous research. In this review, we discuss three basic mechanisms that are commonly observed in both genetic and acquired epilepsies.

\subsection{Ion Channel and Neurotransmitter Dynamics in Epilepsy}

Many voltage- and ligand-gated ion channels are dysregulated in epilepsies caused by both genetic mutations and structural abnormalities $[26,27,31]$. Active exome sequencing can uncover a variety of mutations in sodium, potassium, and calcium channel genes, in addition to gamma-aminobutyric acid (GABA) and NMDA receptor genes [26,27]. We will cover the critical facts concerning some exemplary channel mutations in this review; for more detailed information, refer to [26,27]. Voltage-dependent sodium channels such as SCN1A, SCN2A, SCN3A, SCN8A, SCN9A, and SCN1B, which encode $\mathrm{Na}_{\mathrm{v}} 1.1$, $\mathrm{Na}_{\mathrm{v}} 1.2, \mathrm{Na}_{\mathrm{v}} 1.3, \mathrm{Na}_{\mathrm{v}} 1.6, \mathrm{Na}_{\mathrm{v}} 1.7$, and $\mathrm{Na}_{\mathrm{v}} \beta 1$, respectively, have had many different mutation sites reported for each gene, including both nonsense and missense mutations [26]. This may explain why patients with the same mutation can exhibit variable seizure severity. Moreover, as multiple DNA regions can be mutated within the same gene, it is likely that the SCN1A mutation can be identified in multiple kinds of genetic epilepsies, including severe myoclonic epilepsy of infancy, epilepsy with febrile seizures plus, and partial epilepsy with febrile seizures plus. Although the details of the sodium channel dysfunction differ depending on the individual mutation site, overall changes are made toward channel hyperactivity, promoting neuronal hyperexcitation [32-35]. This explanation is supported by knockout animals showing seizure phenotypes [36-40]. Finally, SCN1A and SCN8A mutations have been associated with sudden unexpected death in epilepsy (SUDEP). Although the etiologic mechanisms behind SUDEP are unclear, the association between refractory seizures by SCN1A and SCN8A mutations and disrupted cardiorespiratory function has been proposed as a risk factor for SUDEP [34,41-45].

With regard to potassium channels, KCNQ2 and KCNQ3 mutations are frequently observed in patients with self-limited familial neonatal seizures [46]. KCNQ2 and KCNQ3 encode voltage-gated potassium channels that produce the $\mathrm{M}$ current, inducing a hyperpolarizing shift in membrane voltage. Loss of their function can increase neuronal hyperexcitability, leading to spontaneous seizure activities as reported in KCNQ2 and KCNQ3 knockout mice [47]. Among calcium channel mutations, CACNA1H, a T-type calcium channel subunit called $\mathrm{Ca}_{\mathrm{v}} 3.2$, has shown three missense mutations in patients with genetic generalized epilepsy and has displayed enhanced channel function $[48,49]$. As for ligand-gated ion channels such as $\mathrm{GABA}_{\mathrm{A}}$ and glutamate NMDA receptors, GABRA1, GABRB3, and GABRG2 mutations encoding $\alpha 1, \beta 3$, and $\gamma 2$ subunits of GABA $_{A}$ receptor, and GRIN1, GRIN2A, GRIN2B, and GRIN2D mutations encoding NR1, NR2A, NR2B, and NR2D subunits of NMDA receptors, respectively, have been identified in genetic epilepsy [27]. Similarly to the other channel mutations described above, most mutations of $\mathrm{GABA}_{\mathrm{A}}$ receptors cause loss of function, whereas mutations of NMDA receptors induce the gain of function of NMDA receptors [27], anticipating network hyperexcitability in these genetic epilepsies. 
Ion channel abnormalities have also been examined extensively in acquired epilepsy, including TLE [31]. In general, individual perturbations of many different ion channels occur toward the facilitation of network hyperexcitability. For example, transcription of the T-type calcium channel $\mathrm{Ca}_{\mathrm{v}} 3.2$ was shown to be upregulated after pilocarpine-induced status epilepticus [50], which can change the mode of neuronal firing from regular to intrinsic burst firing after acute seizures [51,52], strengthening the propensity of neuronal excitation. Other important players mediating abnormal neuronal transmission in TLE are ligand-gated GABA and glutamate receptors. Failure of GABAergic inhibition contributes to the development of epilepsy [53,54]. It may accompany enhanced excitatory transmission by molecular re-assembly of $\alpha$-amino-3-hydroxy-5-methyl-4-isoxazolepropionic acid receptor subunits, as GluR2 transcription has been shown to decrease after status epilepticus [55], suggesting a possible increase in calcium permeability through this receptor [56]. Alterations of $\mathrm{GABA}_{\mathrm{A}}$ receptor subtypes in TLE can also participate in compensation of the seizure-induced imbalance between excitation and inhibition, contributing to complex epileptogenesis [57].

\subsection{Oxidative Stress in Epilepsy}

Reactive oxygen species (ROS) contain unpaired electrons. Common free radicals generated in cells include superoxides, hydroxyl radicals, and hydrogen peroxide. These ROS can be produced as a byproduct of physiological mitochondrial respiration [58] or the activation of cellular enzymes such as nitric oxide synthase, cyclooxygenase (COX), lipoxygenase, xanthine oxidase, cytochrome P450, and nicotinamide adenine dinucleotide phosphate oxidase [59]. Numerous experimental studies have reported excessive ROS production in epilepsies that exceeds the capability of endogenous antioxidants such as superoxide dismutase (SOD) and thioredoxin reductases [60]. The resulting oxidative stress after seizure activities can lead to peroxidation of cellular macromolecules such as proteins, lipids, and DNA. These alterations undermine cellular function in general because protein oxidation can change the structure and activity of crucial enzymes such as sodium-potassium ATPase [61]. ROS-induced alteration of sodium-potassium ATPase can then impair the efficient reversal of neuronal depolarization-induced electrochemical gradients, causing excitotoxicity. In addition, peroxidation can alter the properties of lipid bilayers, influencing membrane permeability and the activity of membrane proteins, including ion channels, and ligand-gated neurotransmitter receptors [62]. Together, excessive ROS-mediated oxidative stress induced by seizures can predispose neuronal hyperexcitability.

Some genetic epilepsies exhibit mitochondrial DNA mutations affecting complex I of an electron transport chain [63,64]. Intractable myoclonic epilepsy with ragged-red fibers (MERRF) and Leigh syndrome have displayed increased ROS production due to complex I dysfunction $[65,66]$. When the MERRF gene is mutated, impairments of mitochondrial calcium uptake and ATP synthesis, which can trigger cellular energy deficiency-initiated neuronal excitotoxicity, are observed [67]. Moreover, a thioredoxin reductase 1 mutation reported in patients with genetic generalized epilepsy can increase sensitivity to hydrogen peroxide challenges [68], implying insufficient ROS detoxification. Another study has identified patients with Lafora disease as showing progressive myoclonic epilepsy and the mutation of glucan phosphatases EPM2A and EPM2B $[69,70]$. Fibroblasts obtained from Lafora disease patients have been shown to exhibit increased production of ROS, including mitochondrial superoxide, along with a reduction in mitochondrial SOD and catalase expression [70]. This has been further supported by both EPM2A and EPM2B knockout mice exhibiting reduced SOD activity in addition to increased levels of lipid peroxidation, suggesting defective cellular processes that reduce oxidative stress by genetic mutations. These pieces of evidence collectively support the idea of elevated oxidative stress in the pathophysiology of various genetic epilepsies.

In acquired epilepsy syndromes, multiple reports have consistently shown that seizures induce oxidative damage following excessive ROS generation in the brain, exacerbating network excitability $[59,60,71]$. Various markers of protein and lipid peroxidation have been reportedly increased in surgically-resected human TLE tissues [72-75], despite upregulated glutathione and SOD antioxidant systems $[73,76,77]$, suggesting seizure-induced oxidative damage. Animal studies have also confirmed 
increased ROS production in the hippocampus in association with oxidative damage to proteins, lipids, and mitochondrial DNA [78-83]. A cause-and-effect relationship between oxidative stress and the development of epilepsy has been suggested by reports that spontaneous recurrent seizures in SOD mutant mice are correlated with augmented oxidative damage and neuronal death due to insufficient antioxidant expression [84,85]. In summary, these results emphasize the important role of oxidative stress in epileptogenesis and related neuropathology.

\subsection{Inflammation in Epilepsy}

The majority of genetic-epilepsy-associated genes studied to date involve ion channels and a few strands of mitochondrial DNA. Little has been reported with respect to inflammatory cytokines and enzymes. However, two papers investigating single-nucleotide polymorphisms of interleukin $1 \beta$ (IL-1 $\beta$ ) in patients with febrile seizures have raised the possibility of de novo mutations [86,87]. They found that IL-1 $\beta$ TT genotypes were over-represented in febrile seizure-experiencing groups compared with healthy controls. Moreover, serum IL-1 $\beta$ concentration was significantly higher in patients experiencing febrile seizures, suggesting that an IL-1 $\beta$ polymorphism may promote proinflammatory conditions after febrile seizures and contribute to the development of TLE in a chronic phase.

In the hippocampus, activation of astrocytes and microglia has been consistently observed after acute seizures in multiple types of epilepsy, including TLE, tuberous sclerosis complex, traumatic brain injury, Rasmussen syndrome, and focal cortical dysplasia [88,89]. Activated glial cells can release various inflammatory mediators, including IL-1 $\beta$, high mobility group box-1 (HMGB1), interleukin 6 (IL-6), tumor necrosis factor $\alpha$ (TNF- $\alpha)$, COX-2, and complementary factors after acute seizures [90]. Glial cells respond rapidly to seizure activities as cytokine levels in the brain increase within $30 \mathrm{~min}$ of seizure onset and stay at high levels even in chronic epileptic stages [88]. With regard to the many inflammatory mediators released in epileptogenic brains, the pro-epileptic roles of IL- $1 \beta$ are well established. Upregulated IL-1 $\beta$ and its inhibition by interleukin 1 receptor agonist have been found to facilitate and alleviate the induction of status epilepticus, respectively, with the regulation of glutamatergic neurotransmission [91,92]. Moreover, proinflammatory cytokines increase blood-brain barrier (BBB) permeability, supporting dynamic relationships among BBB breakdown, inflammation, and reactive glial activation [91]. HMGB1, another pro-epileptic mediator that can be secreted by glial cells and dead neurons, acts through a toll-like receptor (TLR) system [93]. Increased expression of HMGB1 and TLR4 is seen in TLE and focal cortical dysplasia [93]; HMGB1 can enhance both acute and chronic seizure susceptibilities in a TLR4-dependent manner [94].

IL-6 can be anti-epileptic, and, as experimental and clinical evidence has shown, it is involved in glutamatergic receptor-mediated acute seizure aggravation $[95,96]$. However, TNF- $\alpha$ can serve either pro- or anti-epileptic roles, depending on the context. For example, TNF- $\alpha$ infusion into the lateral ventricle can increase seizure susceptibility [97], supporting the pro-epileptogenic effects of TNF- $\alpha$. Moreover, TNF- $\alpha$ has demonstrated a pro-convulsive effect involving activation of TNF- $\alpha$ receptor 1 but an opposite anti-ictogenic effect has also been observed when TNF- $\alpha$ signaling is mediated by TNF- $\alpha$ receptor 2 [98]. In support of the anticonvulsive effects of TNF- $\alpha$ signaling pathways, knockout of TNF- $\alpha$ and its receptor p75 using a genetic approach has shown exacerbated seizures with aggravated cell death [99].

Multiple proinflammatory and anti-inflammatory mediators secreted by activated glial cells can play multifaceted roles in various types of epilepsy, affecting the network excitability. As their modes of action are complex and intricate, a deeper appreciation of the underlying mechanism will provide valuable insights into the complicated pathophysiology of epilepsy. 


\section{Functional Nutrients Beneficial in Epilepsy}

A variety of nutritional interventions have been carried out in patients with epilepsy to investigate the clinical significance of functional nutrients in the control of seizures. Despite ample experimental evidence demonstrating the therapeutic potential of various nutrients, clinical data assessing the anticonvulsive effects of nutritional supplements are scarce. In this section we introduce several nutrients that have demonstrated beneficial effects in multiple clinical studies and explore their possible molecular mechanisms.

\subsection{Omega-3 Polyunsaturated Fatty Acids}

Omega-3 polyunsaturated fatty acids (n-3 PUFAs) are essential fatty acids that cannot be synthesized in sufficient quantities in the body. They must therefore be obtained from the diet or supplements. Marine fish (salmon, tuna, and mackerel), nuts and seeds (flaxseed, chia seeds, almonds, and walnuts) are rich in dietary n-3 PUFAs [100]. The three major omega-3 fatty acids are docosahexaenoic acid (DHA) and eicosapentaenoic acid (EPA), which are found mainly in marine fish oils, and alpha-linolenic acid (ALA), which is the main component of plant oils. Among these three, DHA is the primary n-3 PUFA in the brain and constitutes $10-20 \%$ of total brain fatty acids, whereas ALA and EPA constitute less than 1\% [101]. DHA can serve as a structural component of neuronal membranes, modulating membrane biophysical properties [102], ion channel functions [103], and neurotransmitter signaling [104].

The therapeutic benefits of omega-3 fatty acids for epilepsy have been anticipated, as n-3 PUFA can reduce cardiac arrhythmia, which involves the hyperexcitability of cardiac cells [105]. The first clinical, open-label study of the therapeutic potential of fish oil in patients with epilepsy found an anticonvulsive effect associated with n-3 PUFA [4]. However, subsequent clinical studies have produced more controversial results (Table 1). For example, while some randomized clinical trials have found that consuming approximately $0.6-2 \mathrm{~g}$ of fish oil reduces seizure frequency and duration [5-9], other small-scale, non-randomized studies have reported no regulatory efficacy for seizures [10,106-109]. Despite several animal studies suggesting omega-3 fatty acids suppress seizures, whether n-3 PUFA has significant benefits regarding the control of seizures remains unclear. Still, considering the goal of identifying nutritional supplements that assist drug therapy, and given the established safety of fish oil at dosages of less than $4 \mathrm{~g}$ per day, fish oil can be recommended for the regulation of seizure generation [110].

A consequential issue in addition to seizure control is SUDEP, a leading cause of death in patients with intractable epilepsy [111,112]. Based on the strong beneficial roles of n-3 PUFAs in the attenuation of arrhythmia and sudden cardiac death $[105,113]$, it is plausible that fish oil may promote cardiac health. Many researchers have tried to link n-3 PUFA to the prevention of SUDEP via the reduction of cardiac arrhythmias [114-117]. A randomized double-blind study assessing 11 patients with intractable epilepsy provided initial evidence that fish oil supplementation could restore heart rate variability (HRV) in a subgroup with very low baseline HRV, which can be a marker of sudden death risk [10]. However, as this is the only study implicating n-3 PUFA supplementation in SUDEP prevention, more efforts are warranted before drawing conclusions regarding the efficacy of omega- 3 fatty acids in epilepsy-associated mortality. 
Table 1. Clinical studies assessing the efficacy of fish oil in patients with epilepsy.

\begin{tabular}{|c|c|c|c|c|c|c|c|c|}
\hline \multirow{2}{*}{ Author } & \multirow{2}{*}{$\begin{array}{l}\text { Number of } \\
\text { Patients }\end{array}$} & \multirow{2}{*}{ Age (years) } & \multirow{2}{*}{ Study Type } & \multicolumn{2}{|c|}{ Intervention } & \multirow{2}{*}{ Duration } & \multirow{2}{*}{$\begin{array}{l}\text { Any Other } \\
\text { Intervention }\end{array}$} & \multirow{2}{*}{ Final Result } \\
\hline & & & & Experimental (Exp) & Control (Con) & & & \\
\hline $\begin{array}{l}\text { Schlanger et } \\
\text { al., } 2002[4]\end{array}$ & $n=5$ & Range: $12-26$ & Observational & $5 \mathrm{~g}$ DHA, EPA, ALA & - & 24 weeks & $\begin{array}{l}\text { Anticonvulsive } \\
\text { drugs }\end{array}$ & $\begin{array}{l}\text { Decreased seizures after } \\
\text { intervention }\end{array}$ \\
\hline $\begin{array}{l}\text { Yuen et al., } \\
2005[5]\end{array}$ & $\begin{array}{l}n=57 \text { (Exp: } \\
13 \text {, Con: 22) }\end{array}$ & Range: $19-65$ & $\begin{array}{l}\text { Randomized, } \\
\text { double-blind, } \\
\text { placebo-controlled trial }\end{array}$ & $\begin{array}{c}1000 \mathrm{mg} \text { fish oil }(171 \mathrm{mg} \text { EPA, } \\
112 \mathrm{mg} \text { DHA, }<100 \mathrm{IU} \text { Vit A, }<40 \\
\text { IU Vit D) }\end{array}$ & $\begin{array}{l}\text { Placebo ( } 70 \% \text { palm olein, } \\
15 \% \text { rapeseed oil, } 15 \% \\
\text { sunflower oil) }\end{array}$ & 12 weeks & Antiepileptic drugs & $\begin{array}{l}\text { First } 6 \text { weeks: five had } 50 \% \\
\text { reduction in seizures } \\
\text { Second } 6 \text { weeks: no difference }\end{array}$ \\
\hline $\begin{array}{l}\text { Puri et al., } \\
2007 \text { [106] }\end{array}$ & $\begin{array}{l}n=7(\text { Exp: } \\
3, \text { Con: } 4)\end{array}$ & $\begin{array}{c}\text { Mean } \pm \text { SD: } 50.7 \\
\pm 13.6 \text { (Exp) } \\
40.5 \pm 12.0 \text { (Con) }\end{array}$ & $\begin{array}{l}\text { Randomized, } \\
\text { double-blind, } \\
\text { placebo-controlled trial }\end{array}$ & $\begin{array}{c}1000 \mathrm{mg} \text { fish oil }(171 \mathrm{mg} \text { EPA, } \\
112 \mathrm{mg} \text { DHA, }<100 \text { IU Vit A, }<40 \\
\text { IU Vit D) }\end{array}$ & $\begin{array}{l}\text { Placebo ( } 70 \% \text { palm olein, } \\
15 \% \text { rapeseed oil, } 15 \% \\
\text { sunflower oil) }\end{array}$ & 12 weeks & - & $\begin{array}{l}\text { No significant correlations } \\
\text { between seizures and changes in } \\
\text { spectroscopic resonances }\end{array}$ \\
\hline $\begin{array}{l}\text { Dahlin et al., } \\
2007 \text { [107] }\end{array}$ & $n=25$ & Range: $1.5-18.1$ & Prospective cohort & $\begin{array}{l}\text { 1-2 g fish oil with meal, four } \\
\text { times/day }\end{array}$ & 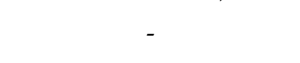 & 48 weeks & Antiepileptic drugs & No effect on seizures \\
\hline $\begin{array}{l}\text { Bromfield et } \\
\text { al., 2008 } \\
\text { [108] }\end{array}$ & $\begin{array}{l}n=21,(\text { Exp: } \\
12, \text { Con: } 9)\end{array}$ & $\begin{array}{c}\text { Range: } \\
\text { 25-55 (Exp), } \\
\text { 22-62 (Con) }\end{array}$ & $\begin{array}{l}\text { Randomized, } \\
\text { double-blind, } \\
\text { placebo-controlled trial } \\
\text { Randomized, }\end{array}$ & $\begin{array}{c}2.2 \mathrm{mg} \text { EPA and DHA (3:2 ratio) } \\
1.1 \mathrm{~g} / \text { day ( } 1 \text { week) } \rightarrow 1.1 \mathrm{~g} \text {, two } \\
\text { times/day ( } 3 \text { weeks) }\end{array}$ & Mineral oil & 4 weeks & Antiepileptic drugs & No effect on seizures \\
\hline $\begin{array}{l}\text { DeGiorgio et } \\
\text { al., 2008 [10] }\end{array}$ & $n=11$ & Range: $18-65$ & $\begin{array}{l}\text { double-blind, two } \\
\text { periods crossover clinical } \\
\text { trial, } 6 \text { weeks washout } \\
\text { period }\end{array}$ & $\begin{array}{c}1200 \mathrm{mg} \text { fish oil/day (216 mg } \\
\text { EPA, } 144 \mathrm{mg} \text { DHA) }\end{array}$ & $\begin{array}{c}\text { Soybean oil } \\
8 \text { capsules/day }\end{array}$ & 30 weeks & Antiepileptic drugs & $\begin{array}{l}\text { No effect on seizures } \\
\text { Restoration of heart rate } \\
\text { variability }\end{array}$ \\
\hline $\begin{array}{l}\text { Al Khayat et } \\
\text { al., } 2010[6]\end{array}$ & $n=20$ & Range: $3-10$ & Observational & $\begin{array}{c}1000 \text { mg PUFA (700 mg DHA } \\
\text { and } 300 \text { mg EPA) }\end{array}$ & & 6 months & Antiepileptic drugs & $\begin{array}{l}\text { Decreased seizure frequency, } \\
\text { seizure duration and seizure } \\
\text { severity after intervention }\end{array}$ \\
\hline $\begin{array}{l}\text { Yuen et al., } \\
2012 \text { [109] }\end{array}$ & $n=10$ & Range: $23-75$ & Observational & $\begin{array}{c}500 \text { mg EPA with } 10 \text { mg mixed } \\
\text { tocopherols/capsule, } 2 \\
\text { capsules/day }\end{array}$ & - & 12 weeks & Antiepileptic drugs & $\begin{array}{c}\text { No effect on seizures } \\
\text { Reduced seizure severity in one } \\
\text { person }\end{array}$ \\
\hline $\begin{array}{l}\text { DeGiorgio et } \\
\text { al., } 2015 \text { [7] }\end{array}$ & $n=24$ & Range: $18-56$ & $\begin{array}{c}\text { Randomized, } \\
\text { double-blind, three } \\
\text { periods crossover clinical } \\
\text { trial, twice } 6 \text { weeks } \\
\text { washout }\end{array}$ & $\begin{array}{c}\text { Fish oil capsule (216 mg EPA, } 144 \\
\text { mg DHA (360 mg fatty } \\
\text { acids/capsules)) Low-dose group: } \\
1080 \mathrm{mg} / \text { day } \\
\text { High-dose group: } 2160 \mathrm{mg} / \text { day }\end{array}$ & $\begin{array}{l}3 \text { corn oil capsules/twice } \\
\text { day }\end{array}$ & 42 weeks & Antiepileptic drugs & $\begin{array}{l}\text { Decreased seizures in low-dose } \\
\text { fish oil }\end{array}$ \\
\hline $\begin{array}{l}\text { Reda et al., } \\
2015 \text { [8] }\end{array}$ & $n=70$ & $\begin{array}{l}\text { Range: } 4-12 \\
\text { Mean } \pm \text { SD: } 6.9 \\
\pm 2.5 \text { (Exp), } 6.6 \\
\pm 2.4 \text { (Con) }\end{array}$ & $\begin{array}{l}\text { Randomized, single-blind } \\
\text { trial }\end{array}$ & $\begin{array}{l}1200 \mathrm{mg} \text { fish oil ( } 240 \mathrm{mg} \text { DHA, } \\
360 \mathrm{mg} \text { EPA, Vit E) }\end{array}$ & Corn oil & 12 weeks & Antiepileptic drugs & $\begin{array}{l}\text { Elevated the seizure threshold in } \\
\text { fish oil supplementation group }\end{array}$ \\
\hline $\begin{array}{l}\text { Omrani et } \\
\text { al., } 2019 \text { [9] }\end{array}$ & $n=50$ & Range: $18-55$ & $\begin{array}{l}\text { Randomized, triple-blind, } \\
\text { placebo-controlled trial }\end{array}$ & $\begin{array}{c}\text { Omega-3 fatty acids capsules } \\
\text { (120 mg DHA, } 180 \text { mg EPA plus } \\
\text { Vit E) }\end{array}$ & Placebo capsule & $\begin{array}{l}16 \text { weeks } \\
\text { (two times/ } \\
\text { day) }\end{array}$ & $\begin{array}{l}\text { Antiepileptic drugs } \\
\text { in refractory } \\
\text { epilepsy }\end{array}$ & $\begin{array}{l}\text { Decreased seizure frequency and } \\
\text { duration in omega-3 fatty acids } \\
\text { supplementation group }\end{array}$ \\
\hline
\end{tabular}

Legend: DHA, docosahexaenoic acid; EPA, eicosapentaenoic acid; ALA, alpha-linolenic acid; PUFAs, polyunsaturated fatty acids; Vit, vitamin; -, not indicated; IU, international unit. 
An elevated seizure threshold associated with n-3 PUFAs has been verified in a variety of animal models [103,118-124]. With regard to the possible underlying molecular mechanisms of n-3 PUFA-mediated anticonvulsive effects, the regulation of ion channel activities, as well as anti-oxidative and anti-inflammatory effects, has been proposed. For example, PUFAs can inactivate neuronal voltage-dependent sodium and calcium channels $[125,126]$. Moreover, DHA, ALA, and EPA treatment of mouse dorsal root ganglion neurons reportedly facilitates the opening of potassium M-channels, dampening neuronal activity [127]. DHA can also modulate ionotropic $\mathrm{GABA}_{\mathrm{A}}$ receptors, alleviating neuronal hyperactivities [104,128-130]. Increasing inhibitory potentials by n-3 PUFA-associated ion channel modulation can result in improved survival of GABAergic interneurons and excitatory pyramidal neurons in the hippocampus after pilocarpine-induced status epilepticus, as n-3 PUFAs may stabilize seizure-induced hyperexcitable states [131,132]. Another possible mechanism is the anti-oxidative effect of omega-3 fatty acids. Using the pentylenetetrazole model of epilepsy, several researchers have demonstrated that n-3 PUFA administration increases SOD, catalase, and glutathione peroxidase activity and expression $[122,124,133]$. This relationship has been further supported by a different model of epilepsy, reinforcing the anti-oxidative function of n-3 PUFAs [134]. When a recent randomized clinical trial assessed cytokine levels after 16 weeks of n-3 PUFA treatment, TNF- $\alpha$ and IL-6 concentrations were found to significantly decrease in the supplemented group compared to the placebo group [9]. In the pilocarpine model of epilepsy, proinflammatory cytokines in the blood of omega-3 fatty acid-treated rats, including IL-1B, TNF- $\alpha$, and IL-6, all decreased [135], supporting the anti-inflammatory role of n-3 PUFAs in epilepsy.

\subsection{Vitamin D3 (Cholecalciferol)}

Vitamin D is a fat-soluble vitamin that comes in multiple forms, including vitamin D2 (ergocalciferol) and D3 (cholecalciferol). Among these, vitamin D3 is naturally present in animals and can be synthesized by exposure to sunlight. However, vitamin $\mathrm{D}$ can also be obtained from dietary sources such as oily fish (cod, swordfish, salmon, tuna, and sardines), dairy products (milk, cheese, and yogurt), meat (beef liver), and mushrooms [136]. Once vitamin D is produced or ingested, the liver converts it to 25-hydroxyvitamin D (25-OH vitamin D, calcidiol). The kidney then makes the active form, 1,25-dihydroxyvitamin $\mathrm{D}\left(1,25-[\mathrm{OH}]_{2}\right.$ vitamin $\mathrm{D}$, calcitriol) [137]. Vitamin D3 maintains bone integrity by promoting the absorption of calcium and phosphorus. In the brain, vitamin $\mathrm{D}$ is a neuroactive steroid, acting through nuclear or membrane vitamin D receptors [138]. Functions of vitamin D in the central nervous system include regulation of neurotransmitters, neuronal differentiation, axonal growth, voltage-sensitive calcium channels, neurotrophic factors, and ROS [138], which can affect proper neuronal function.

Several studies have reported that both young and adult patients with epilepsy show vitamin D deficiency in their blood [139-141], providing a rationale for giving vitamin D to people with epilepsy. To date, three clinical studies have investigated the effects of vitamin D on seizure control (Table 2) [11-13]. The first study recruited 23 epileptic patients who were divided into two experimental groups, with one given 4000 international units (IU) of vitamin D3 daily for 28 days and 16,000 IU of vitamin D3 for the next 28 days, followed by an initial observation period, and the other given the placebo first and then 8000 IU of vitamin D3 for each of the 28-day periods [11]. In patients who received vitamin D3, the mean seizure frequency was significantly reduced to $67-71 \%$ of that of the baseline, suggesting an anticonvulsive effect. A similar observation has reported in another clinical study in which correction of vitamin D3 deficiency reduced seizure frequency by up to $40 \%$ for drug-resistant epilepsy [12]. A recent cross-sectional cohort study which assessed 160 patients with epilepsy, however, has reported conflicting results which have shown no therapeutic efficacy of vitamin D3 on control of seizure generation [13]. More elaborately designed studies with larger sample sizes will be required to resolve question of the anticonvulsive effects of vitamin D3 with regard to epilepsy. 
Table 2. Clinical studies assessing the efficacy of vitamin D in patients with epilepsy.

\begin{tabular}{|c|c|c|c|c|c|c|c|c|}
\hline \multirow{2}{*}{ Author } & \multirow{2}{*}{$\begin{array}{c}\text { Number of } \\
\text { Patients }\end{array}$} & \multirow{2}{*}{ Age (Years) } & \multirow{2}{*}{ Study Type } & \multicolumn{2}{|c|}{ Subgroup } & \multirow{2}{*}{ Duration } & \multirow{2}{*}{$\begin{array}{l}\text { Any Other } \\
\text { Intervention }\end{array}$} & \multirow{2}{*}{ Final Results } \\
\hline & & & & PWE & Control (Con) & & & \\
\hline $\begin{array}{l}\text { Christiansen } \\
\text { et al., } 1974 \\
\text { [11] }\end{array}$ & $n=23$ & Range: 6-27 & Observational & $\begin{array}{c}\text { A: } N=9,4000 \mathrm{IU}, \\
16,000 \mathrm{IU} / \text { day Vit } \mathrm{D} 3 \\
\mathrm{~B}: \mathrm{N}=14,8000 \mathrm{IU} / \text { day } \\
\text { Vit D3 }\end{array}$ & & 84 days & $\begin{array}{l}\text { Antiepileptic } \\
\text { drugs }\end{array}$ & $\begin{array}{l}\text { Reduction in the number } \\
\text { of seizures after } \\
\text { intervention }\end{array}$ \\
\hline $\begin{array}{l}\text { Hollo et al., } \\
2012 \text { [12] }\end{array}$ & $n=13$ & $\begin{array}{l}\text { Range: } \\
19-60\end{array}$ & Observational & Vit D3 & & 90 days & - & $\begin{array}{l}40 \% \text { decrease in seizures } \\
\text { after intervention }\end{array}$ \\
\hline $\begin{array}{l}\text { Tombini et } \\
\text { al., } 2018 \text { [13] }\end{array}$ & $\begin{array}{l}n=202 \text { (PWE: } \\
\text { 160, Con: 42) }\end{array}$ & $\begin{array}{l}\text { Mean } \pm \text { SD: } \\
50.6 \pm 19.3\end{array}$ & $\begin{array}{l}\text { Case-sectional } \\
\text { cohort }\end{array}$ & $\begin{array}{c}\text { Cholecalciferol 100,000 } \\
\text { IU/week (Vit D } \\
\text { deficiency) } \\
\text { Cholecalciferol 100,000 } \\
\text { IU/2 weeks (Vit D } \\
\text { insufficiency) }\end{array}$ & $\begin{array}{c}\text { Cholecalciferol 100,000 } \\
\text { IU/week (Vit D } \\
\text { deficiency) } \\
\text { Cholecalciferol 100,000 } \\
\text { IU/2 weeks (Vit D } \\
\text { insufficiency) }\end{array}$ & 3 months & $\begin{array}{l}\text { Antiepileptic } \\
\text { drugs }\end{array}$ & $\begin{array}{l}\text { PWE showed low Vit D } \\
\text { No effect on } \\
\text { drug-resistant seizures }\end{array}$ \\
\hline
\end{tabular}

Legend: PWE, patients with epilepsy; -, not indicated. 
Because vitamin D3 has versatile therapeutic efficacies on cardiovascular diseases [142], vitamin D3 may have an impact on SUDEP [143]. Although there is no direct evidence demonstrating a possible role for vitamin D in SUDEP prevention, one group has reported that vitamin D supplementation can modulate HRV [144-147], which is frequently lower in patients with drug-refractory epilepsy, a group at high risk of SUDEP $[148,149]$. This raises the possibility that vitamin D may have therapeutic benefits for the prevention of SUDEP.

Animal models of epilepsy have also indicated anticonvulsive effects from vitamin D treatment [150-153]. When the vitamin D receptor has been genetically deleted, seizure susceptibility has been significantly augmented in epileptic mice [154]. Possible mechanisms of vitamin-D3-mediated anticonvulsive effects include a reduction in voltage-sensitive calcium channel expression $[155,156]$ via the attenuation of neuronal calcium overload after seizure activities. Vitamin D can also inhibit the generation of inducible nitric oxide synthase, which relieves oxidative cellular damage by blocking nitric oxide production [157]. In addition, the immunomodulatory action of vitamin D has been suggested, as vitamin D can suppress various cytokines, including interferon (IFN)- $\gamma$, IL-2, TNF- $\alpha$, and IL-6 [158,159]. We have also reported that an edible mushroom, Hericium erinaceus, in which ergosteol can be converted to vitamin D [160], may protect hippocampal neurons against pilocarpine-induced status epilepticus by decreasing COX-2-expressing glial cells [161]. The idea of the anti-inflammatory properties of vitamin $\mathrm{D}$ has been further supported by a clinical study that reported how concentrations of IL- $1 \beta$, IL-6, interleukin- 8 , macrophage inflammatory protein $1 \beta$, monocyte chemoattractant protein-1, and IFN-inducible protein 10 markedly decreased after co-treatment with vitamins D and B12. In summary, vitamin D appears to be a promising candidate that will complement epilepsy treatment with antiepileptic drugs.

\subsection{Vitamin $E$}

Vitamin E refers to a group of fat-soluble antioxidants [162]. Vitamin E consists of eight vitamer chemicals with similar molecular structures and functions, namely, four tocopherols $(\alpha-, \beta-, \gamma-$, and $\delta$-tocopherols) and four tocotrienols $(\alpha-, \beta-, \gamma-$, and $\delta$-tocotrienols). Among these, $\alpha$-tocopherol is the most biologically active in humans. Vitamin $\mathrm{E}$ is found in nuts, seeds, vegetable oils, and green leafy vegetables such as spinach and broccoli [162]. Well known for its anti-oxidative role, vitamin $\mathrm{E}$ has been associated with versatile health promotion and additive effects in treatments for many diseases, including cardiovascular, hepatic, and Alzheimer's diseases [163-165].

For epileptic patients, $400 \mathrm{IU}$ of daily vitamin E supplementation for three months has been shown to reduce seizure frequency by approximately $60 \%$ compared with a placebo group that showed no difference in the number of seizures (Table 3) [14]. Two other clinical studies have confirmed the beneficial effects of chronic vitamin E administration in patients with refractory epilepsy $[15,16]$, supporting the use of vitamin $\mathrm{E}$ as an adjunctive therapeutic option for epilepsy. However, the authors of another randomized, double-blind clinical trial have reported that vitamin E supplementation over three months did not affect the occurrence of seizures regardless of the different types of epilepsy (Table 3) [166]. 
Table 3. Clinical studies assessing the efficacy of vitamin E in patients with epilepsy.

\begin{tabular}{|c|c|c|c|c|c|c|c|c|}
\hline \multirow{2}{*}{ Author } & \multirow{2}{*}{$\begin{array}{l}\text { Number of } \\
\text { Patients }\end{array}$} & \multirow{2}{*}{ Age (years) } & \multirow{2}{*}{ Study Type } & \multicolumn{2}{|c|}{ Intervention } & \multirow{2}{*}{ Duration } & \multirow{2}{*}{$\begin{array}{l}\text { Any Other } \\
\text { Intervention }\end{array}$} & \multirow{2}{*}{ Final Results } \\
\hline & & & & Experimental (Exp) & Control (Con) & & & \\
\hline $\begin{array}{c}\text { Ogunmekan } \\
\text { et al., } 1989 \\
{[14]}\end{array}$ & $\begin{array}{l}n=24 \text { (Exp: } \\
\text { 12, Con: } 12)\end{array}$ & Range: 6-17 & $\begin{array}{c}\text { Randomized, } \\
\text { double-blind, } \\
\text { placebo-controlled } \\
\text { clinical trial }\end{array}$ & Vit E & Placebo & 3 months & $\begin{array}{l}\text { Antiepileptic } \\
\text { drugs }\end{array}$ & $\begin{array}{l}>60 \% \text { reduction in } \\
\text { seizure frequency }\end{array}$ \\
\hline $\begin{array}{l}\text { Hom et al., } \\
1991 \text { [15] }\end{array}$ & $\begin{array}{l}n=52(\text { Exp: } \\
\text { 27, Con: } 25)\end{array}$ & - & $\begin{array}{c}\text { Randomized, } \\
\text { double-blind, } \\
\text { placebo-controlled trial }\end{array}$ & Vit E & Placebo & 3 months & $\begin{array}{l}\text { Antiepileptic } \\
\text { drugs }\end{array}$ & $\begin{array}{c}\text { Reduction in seizure } \\
\text { frequency: } 30 \% \text { of all } \\
\text { patients } \\
\text { Reduction in seizure } \\
\text { frequency: } 58 \% \text { of } \\
\text { medically stable } \\
\text { patients }\end{array}$ \\
\hline $\begin{array}{l}\text { Raju et al., } \\
1994 \text { [166] }\end{array}$ & $n=43$ & - & $\begin{array}{c}\text { Randomized, } \\
\text { double-blind, two } \\
\text { periods crossover trial }\end{array}$ & $\begin{array}{l}\text { Vit } E \text { and then } \\
\text { placebo }\end{array}$ & $\begin{array}{l}\text { Placebo and } \\
\text { then Vit E }\end{array}$ & $\begin{array}{l}6 \text { months } \\
\text { (for two } \\
\text { treatments) }\end{array}$ & $\begin{array}{l}\text { Antiepileptic } \\
\text { drugs }\end{array}$ & $\begin{array}{l}\text { No significant change } \\
\text { in seizure frequency }\end{array}$ \\
\hline $\begin{array}{l}\text { Mehvari et } \\
\text { al., } 2016 \text { [16] }\end{array}$ & $\begin{array}{l}n=65 \text { (Exp: } \\
\text { 32, Con: } 33)\end{array}$ & $\begin{array}{l}\text { Mean } \pm \text { SD: } 28.8 \\
\pm 5.3 \text { (Exp), } 28.6 \\
\quad \pm 8.8 \text { (Con) }\end{array}$ & $\begin{array}{c}\text { Randomized, } \\
\text { double-blind, } \\
\text { placebo-controlled trial }\end{array}$ & 400 IU/day Vit E & Placebo & 6 months & $\begin{array}{l}\text { Antiepileptic } \\
\text { drugs }\end{array}$ & $\begin{array}{l}\text { Reduction in seizure } \\
\text { frequency } \\
\text { Improved EEG findings }\end{array}$ \\
\hline
\end{tabular}

Legend: EEG, electroencephalogram; -, not indicated. 
Many studies have found an anticonvulsant effect resulting from vitamin E treatment [167-171]. Administered after status epilepticus, it promotes the restoration of glutamate metabolisms by normalizing seizure-induced inhibition of glutamine synthetase (GS), an enzyme that can reduce synaptic glutamate levels [172]. Vitamin E can also inhibit activation of protein kinase C $\delta[173,174]$, which can block GS expression [175], leading to the disinhibition of GS and ultimately the reduction of excitotoxicity. Vitamin E treatment can also offer neuroprotective effects against excessive generation of ROS [176], suggesting anti-oxidative effects. Supporting this hypothesis, many studies investigating preor co-treatment of vitamin $\mathrm{E}$ in animal models of epilepsy have found that vitamin E supplementation can reduce ROS accumulation and attenuate protein and lipid peroxidation [171,173,177-180]. In relation to inflammation enhanced by acute seizures, vitamin E can downregulate the expression of IL-1 $\beta$ and TNF- $\alpha[168,172,177]$, implying an anti-inflammatory function.

\subsection{Vitamin $B 6$}

Vitamin B6 is a water-soluble vitamin that plays a vital role in the development and maintenance of the central nervous system [181]. Dietary vitamin B6 is present in fish (tuna and salmon), meat (beef liver, pork, lamb, and chicken), milk products (cheese and yogurt), grains (yeast bread and biscuits), vegetables (carrots, onion, and tomato), and fruits (berry, apple, watermelon, and banana) $[181,182]$. It has six vitamer chemicals: pyridoxine, pyridoxamine, pyridoxal, pyridoxine $5^{\prime}$-phosphate (PNP), pyridoxamine 5'-phosphate (PMP), and pyridoxal 5'-phosphate (PLP). In general, meat-derived vitamin B6 consists of phosphorylated pyridoxal and pyridoxamine, while plant-derived vitamin B6 contains phosphorylated pyridoxine.

Once pyridoxine, pyridoxamine, and pyridoxal are transferred to the liver after absorption, these vitamers are phosphorylated by pyridoxal kinase to generate PNP, PMP, and PLP, respectively $[183,184]$. Additional conversion of PNP and PMP to PLP can occur by pyridoxine-5'phosphate oxidases (PNPO) to produce a circulatory, active form of vitamin B6 in the blood. As pyridoxal is the only vitamin B6 form that can cross the BBB [185], PLP needs to be hydrolyzed to pyridoxal by tissue non-specific alkaline phosphatase (TNAP). In the neurons, PLP is regenerated by pyridoxal kinases, meaning it can act as an active co-factor [183]. PLP can play a crucial role in the synthesis of multiple neurotransmitters, including GABA, glycine, dopamine, serotonin, and histamine [183]. For example, PLP can convert glutamate to GABA by facilitating the activation of glutamate decarboxylase, suggesting that vitamin B6 deficiency may enhance network excitability in the brain. As we discussed in Section 2.2, pyridoxine deficiency can cause unprovoked seizures which are classified as a type of multifarious epilepsy [3].

Vitamin B6 supplementation has been demonstrated to be beneficial in some, but not all, studies evaluating patients with epilepsy (Table 4). In the 1960s, two clinical studies investigated the effects of vitamin B6 administration on the amelioration of seizures. The researchers found that some patients who received vitamin B6 showed significant clinical improvement, although this was not observed for all patients $[17,18]$. Later, Jiao and colleagues performed a randomized, placebo-controlled trial in which 30 or $50 \mathrm{mg}$ of pyridoxine infusion could resolve the occurrence of recurrent seizures [19]. The total response rate in the pyridoxine-treated group was $92.5 \%$, a significantly higher rate than the control group. However, other clinical studies involving varying types of epilepsy have failed to illustrate anticonvulsive effects following vitamin B6 treatment [186-188]. As all of the clinical studies assessing the therapeutic efficacy of vitamin B6 are small-scale studies interpreting mixed results from various epilepsies, more elaborate studies will be necessary to provide conclusive information about the role of vitamin B6 in epilepsy. 
Table 4. Clinical studies assessing the efficacy of vitamin B6 in patients with epilepsy.

\begin{tabular}{|c|c|c|c|c|c|c|c|c|}
\hline \multirow{2}{*}{ Author } & \multirow{2}{*}{$\begin{array}{l}\text { Number of } \\
\text { Patients }\end{array}$} & \multirow{2}{*}{ Age (years) } & \multirow{2}{*}{ Study Type } & \multicolumn{2}{|l|}{ Intervention } & \multirow{2}{*}{ Duration } & \multirow{2}{*}{$\begin{array}{l}\text { Any Other } \\
\text { Intervention }\end{array}$} & \multirow{2}{*}{ Final Result } \\
\hline & & & & Experimental (Exp) & Control (Con) & & & \\
\hline $\begin{array}{c}\text { Fox and } \\
\text { Tullidge, } 1946 \\
\text { [186] }\end{array}$ & $n=8$ & Range: $14-15$ & Observational & $\begin{array}{c}\text { Four patients: } 100 \mathrm{mg} \\
\text { pyridoxine/day for } 3 \text { weeks } \\
\text { and then } 100 \mathrm{mg} \\
\text { pyridoxine/day for } 4 \text { weeks } \\
\text { Two patients: } 20 \mathrm{mg} / \text { day for } \\
4 \text { weeks and then } 100 \mathrm{mg} \\
\text { pyridoxine/day for } 4 \mathrm{weeks} \\
\text { Two patients: only } 20 \mathrm{mg} / \text { day } \\
\text { for } 8 \text { weeks }\end{array}$ & - & $7-8$ weeks & - & No effects \\
\hline $\begin{array}{l}\text { Livingston et al., } \\
\quad 1955 \text { [187] }\end{array}$ & $n=31$ & Range: $0.5-14$ & Observational & $\begin{array}{l}20 \mathrm{mg} \text { (two times/day); } \\
\text { pyridoxine dosage was } \\
\text { increased to } 100 \mathrm{mg} / \text { day }\end{array}$ & - & At least $1 \mathrm{mo}$ & $\begin{array}{l}\text { Antiepileptic } \\
\text { drugs }\end{array}$ & $\begin{array}{l}\text { Pyridoxine failed to control } \\
\text { seizures } \\
\text { Larger doses of pyridoxine } \\
\text { increased the number of seizures }\end{array}$ \\
\hline $\begin{array}{l}\text { Hagberg et al., } \\
1964 \text { [17] }\end{array}$ & $n=3$ & Range: $1-3$ & Observational & $\begin{array}{l}\text { One patient: } 60 \mathrm{mg} \text { Vit B6 } \\
\text { Two patients: } 160 \mathrm{mg} \text { Vit B6 }\end{array}$ & - & NR & $\begin{array}{l}\text { Antiepileptic } \\
\text { drugs }\end{array}$ & $\begin{array}{l}\text { Improved EEG findings, normal } \\
\text { development, decreased mental } \\
\text { changes, reduced dosage of } \\
\text { anticonvulsive drugs }\end{array}$ \\
\hline $\begin{array}{c}\text { Hansson and } \\
\text { Hagberg, } 1968 \\
\text { [18] }\end{array}$ & $n=56$ & Children & Observational & 160-300 mg pyridoxine & & $\begin{array}{l}\text { At least } 6 \\
\text { weeks }\end{array}$ & $\begin{array}{l}\text { Antiepileptic } \\
\text { drugs }\end{array}$ & $\begin{array}{l}\text { Five patients showed significant } \\
\text { clinical improvement; side effects } \\
\text { for only one patient }\end{array}$ \\
\hline $\begin{array}{c}\text { Heeley et al., } \\
1968[188]\end{array}$ & $n=70$ & Range: $0.2-11$ & Observational & $30 \mathrm{mg} /$ day pyridoxine & - & $1-4$ weeks & $\begin{array}{c}\text { Antiepileptic } \\
\text { drugs }\end{array}$ & No clinical improvement \\
\hline $\begin{array}{l}\text { Jiao et al., } \\
1997[19]\end{array}$ & $\begin{array}{l}n=90,(\text { Exp: } \\
\text { 40, Con: } 50)\end{array}$ & Range: $0.1-12$ & $\begin{array}{l}\text { Randomized, } \\
\text { controlled trial }\end{array}$ & 30 or $50 \mathrm{mg} /$ day pyridoxine & No treatments & NR & $\begin{array}{l}\text { Antiepileptic } \\
\text { drugs }\end{array}$ & Recurrent seizures were resolved \\
\hline
\end{tabular}

Legend: NR, not reported; -, not indicated; mo, month. 
Genetic epilepsies associated with vitamin B6 deficiency include PNPO deficiency, infantile hypophosphatasia, pyridoxine-dependent epilepsy, and type II hyperprolinemia [189]. In an attempt to gain molecular insight, PNPO mutations frequently seen in patients with neonatal epileptic encephalopathy were introduced into Chinese hamster ovary cells, and PNPO activities and subsequent PLP synthesis both declined $[190,191]$, suggesting PNPO-mediated disruption of vitamin B6 synthesis. Infantile hypophosphatasia features a mutation in TNAP, a critical enzyme for the cellular transport of PLP [192]. Indeed, TNAP-deleted mice have displayed increased serum PLP levels due to the reduced availability of cellular PLP and the development of spontaneous seizures with a decrease in total GABA [193]. Moreover, pyridoxine and pyridoxal administration have been found to rescue the seizure phenotype of TNAP mutant mice, providing a molecular mechanism for hypophosphatasia-induced seizures. Pyridoxine-dependent epilepsy is an autosomal recessive disorder with an ALDH7A1 mutation $[20,194]$. ALDH7A1 encodes $\alpha$-aminoadipic semialdehyde dehydrogenase, also known as antiquitin, which generates $\alpha$-aminoadipic acid in the process of lysine catabolism. ALDH7A1 mutation induces antiquitin deficiency, which results in elevated levels of $\alpha$-aminoadipic semialdehyde [194,195]. This can further promote the accumulation of piperidine-6 carboxylate (P6C), which can inactivate PLP by forming a Knoevenagel condensation product [196]. In a zebrafish model of ALDH7A1 deficiency, these reactions were found to lead to an overall reduction of available PLP in the brain and subsequently disrupt conversion of glutamate to GABA, generating spontaneous recurrent seizures [197]. Type II hyperprolinemia is characterized by the mutation of pyrroline-5'-carboxylate dehydrogenase (P5CDH) [20]. P5CDH deficiency can block the conversion of pyrroline-5'-carboxylate (P5C) to glutamate, causing the accumulation of P5C in the blood. As P5C can trap PLP, similar to PLP consumption by $\mathrm{P} 6 \mathrm{C}$, a P5CDH mutation can deplete the available PLP in the brain, causing epilepsy.

\subsection{Nutrients Potentially Beneficial for Refractory Epilepsy}

Vitamin C (also known as L-ascorbic acid) is a water-soluble vitamin that cannot be endogenously synthesized in the human body [198]. Thus, vitamin C needs to be obtained from foods such as citrus fruits (orange and grapefruit), kiwifruits, strawberries, cantaloupes, and certain vegetables (broccoli, tomatoes, brussels sprouts, and red and green peppers) [198]. Vitamin C can act as an antioxidant, scavenging free radicals to protect cells from ROS-associated damages [199]. Moreover, vitamin $C$ can serve as a co-factor in the enzymatic conversion of dopamine to norepinephrine, regulating neurotransmission [200]. Several animal studies have demonstrated the anticonvulsive effects of vitamin $C$, which were seen via the reduction of oxidative stress regardless of model systems, including pilocarpine-, pentylenetetrazol-, penicillin-, or kainic acid-induced epilepsy [180,201-204]. However, even with supporting evidence that patients with epilepsy have shown reduced levels of serum vitamin C [205], no clinical study reporting on the efficacy of vitamin C interventions in epilepsy exists. Currently, only a phase II clinical trial to test the effects of adding vitamin $C$ within the treatment of idiopathic epilepsy (NCT02369822) is ongoing, indicating the requirement of more efforts to elucidate the roles of vitamin C in epilepsy.

Pyruvate is a crucial intermediate in glucose metabolism. Under aerobic conditions, pyruvate can be converted into acetyl coenzyme A, which enters the Krebs cycle to generate adenosine triphosphates, a cellular energy source. Pyruvate can also remove hydrogen peroxides, working as a potent antioxidant [206]. Moreover, a simple derivative of pyruvic acid, ethyl pyruvate can efficiently suppress inflammation [207], suggesting possible therapeutic benefits for epilepsy. Indeed, oral pyruvate administration could significantly reduce the number of spontaneous recurrent seizures in multiple animal models of epilepsy [208]. In addition, a combination therapy of pyruvate, vitamin C, and vitamin E could reduce the formation of seizures [180]. Taken together, these data support the hypothesis that pyruvate may be a novel metabolic target able to be used to treat acquired epilepsies. Based on these preclinical results, clinical trials assessing the therapeutic efficacy of pyruvate will be necessary for the development of new nutrients beneficial for epilepsy. 


\section{Conclusions}

Since phenobarbital became known for its anticonvulsive properties in 1912, numerous antiepileptic drugs have been developed [209]. In spite of a wider array of available options in drug selection today, the incidence of refractory epilepsy remains still high, corresponding to $30 \%$ of all epilepsy patients. Dietary and nutritional supplements can help address this gap until innovative therapeutic methods are established. In this review, we have provided an overview of epilepsy and its fundamental molecular mechanisms, followed by an introduction to several functional nutrients which have the potential to manage seizure frequencies, i.e., omega-3 PUFA, vitamin D3, vitamin E, vitamin B6, vitamin C, and pyruvate. Despite slightly favorable efficacy having been reported in general, there is still controversy surrounding the therapeutic benefits of functional nutrients within epilepsy. We speculate that these discrepancies may come from the inclusion of various epilepsies with different etiologic backgrounds, varied durations of, and different dose regimens and treatment durations of functional nutrients. Thus, more elaborate clinical trials will be required for the accurate evaluation of nutritional supplements for epilepsy, which will enable an informative meta-analysis showing higher levels of evidence to be undertaken in future. Currently, limited dietary and nutritional consideration by patients with epilepsy can be undertaken due to insufficient research attention, which is surprising given the extensive investigative efforts devoted to other diseases, such as Alzheimer's and Parkinson's disease and stroke [210-213]. As experimental evidence regarding putative candidate nutrients in animal models of epilepsy [214-217] is readily available, it will be necessary to examine the translational potential of these molecules to facilitate the development of nutraceuticals for epilepsy treatment. Finally, because of a study in which megavitamin therapy of pyridoxine was shown to cause neurotoxic effects [218], a cautionary note must be included regarding the optimal dose of functional nutrients.

Author Contributions: J.-E.K. and K.-O.C. performed data extraction. J.-E.K. summarized the results of clinical studies. K.-O.C. wrote the manuscript.

Acknowledgments: This work was supported by the National Research Foundation of Korea (NRF) grants funded by the Korean government (NRF-2019R1A2C1003958 to K.-O.C., and NRF-2018R1D1A1A02086055 to J.-E.K.).

Conflicts of Interest: The authors have no conflicts of interest to declare.

\section{References}

1. World Health Organization. Epilepsy Fact sheets. Available online: https://www.who.int/news-room/factsheets/detail/epilepsy (accessed on 7 February 2019).

2. Fisher, R.S.; Acevedo, C.; Arzimanoglou, A.; Bogacz, A.; Cross, J.H.; Elger, C.E.; Engel, J., Jr.; Forsgren, L.; French, J.A.; Glynn, M.; et al. ILAE official report: A practical clinical definition of epilepsy. Epilepsia 2014, 55, 475-482. [CrossRef] [PubMed]

3. Scheffer, I.E.; Berkovic, S.; Capovilla, G.; Connolly, M.B.; French, J.; Guilhoto, L.; Hirsch, E.; Jain, S.; Mathern, G.W.; Moshe, S.L.; et al. ILAE classification of the epilepsies: Position paper of the ILAE Commission for Classification and Terminology. Epilepsia 2017, 58, 512-521. [CrossRef] [PubMed]

4. Schlanger, S.; Shinitzky, M.; Yam, D. Diet enriched with omega-3 fatty acids alleviates convulsion symptoms in epilepsy patients. Epilepsia 2002, 43, 103-104. [CrossRef] [PubMed]

5. Yuen, A.W.; Sander, J.W.; Fluegel, D.; Patsalos, P.N.; Bell, G.S.; Johnson, T.; Koepp, M.J. Omega-3 fatty acid supplementation in patients with chronic epilepsy: A randomized trial. Epilepsy Behav. 2005, 7, $253-258$. [CrossRef] [PubMed]

6. Al Khayat, H.A.; Awadalla, M.M.; Al Wakad, A.; Marwook, Z.A. Polyunsaturated fatty acids in children with idiopathic intractable epilepsy: Serum levels and therapeutic response. J. Pediatr. Neurol. 2010, 8, $175-185$. [CrossRef]

7. DeGiorgio, C.M.; Miller, P.R.; Harper, R.; Gornbein, J.; Schrader, L.; Soss, J.; Meymandi, S. Fish oil (n-3 fatty acids) in drug resistant epilepsy: A randomised placebo-controlled crossover study. J. Neurol. Neurosurg. Psychiatry 2015, 86, 65-70. [CrossRef] [PubMed]

8. Reda, D.M.; Abd-El-Fatah, N.K.; Omar Tel, S.; Darwish, O.A. Fish Oil Intake and Seizure Control in Children with Medically Resistant Epilepsy. N. Am. J. Med. Sci. 2015, 7, 317-321. [CrossRef] 
9. Omrani, S.; Taheri, M.; Omrani, M.D.; Arsang-Jang, S.; Ghafouri-Fard, S. The effect of omega-3 fatty acids on clinical and paraclinical features of intractable epileptic patients: A triple blind randomized clinical trial. Clin. Transl. Med. 2019, 8, 3. [CrossRef]

10. DeGiorgio, C.M.; Miller, P.; Meymandi, S.; Gornbein, J.A. n-3 fatty acids (fish oil) for epilepsy, cardiac risk factors, and risk of SUDEP: Clues from a pilot, double-blind, exploratory study. Epilepsy Behav. 2008, 13, 681-684. [CrossRef]

11. Christiansen, C.; Rodbro, P.; Sjo, O. "Anticonvulsant action" of vitamin D in epileptic patients? A controlled pilot study. Br. Med. J. 1974, 2, 258-259. [CrossRef]

12. Hollo, A.; Clemens, Z.; Kamondi, A.; Lakatos, P.; Szucs, A. Correction of vitamin D deficiency improves seizure control in epilepsy: A pilot study. Epilepsy Behav. 2012, 24, 131-133. [CrossRef] [PubMed]

13. Tombini, M.; Palermo, A.; Assenza, G.; Pellegrino, G.; Benvenga, A.; Campana, C.; Naciu, A.M.; Assenza, F.; Lazzaro, V.D. Calcium metabolism serum markers in adult patients with epilepsy and the effect of vitamin D supplementation on seizure control. Seizure 2018, 58, 75-81. [CrossRef] [PubMed]

14. Ogunmekan, A.O.; Hwang, P.A. A randomized, double-blind, placebo-controlled, clinical trial of D-alpha-tocopheryl acetate (vitamin E), as add-on therapy, for epilepsy in children. Epilepsia 1989, 30, 84-89. [CrossRef] [PubMed]

15. Hom, A.C.; Weaver, R.C.; Aldersen, J.J. Efficacy of D-alpha-tocopheryl acetate as adjuctive antiepileptic agent in patients with refractory epilepsy and profound developmental disability: A prospective, randomized double-blind, placebo-controlled trial. Epilepsia 1991, 32, 62.

16. Mehvari, J.; Motlagh, F.G.; Najafi, M.; Ghazvini, M.R.A.; Naeiru, A.A.; Zare, M. Effects of vitamin E on seizure frequency, electroencephalogram findings, and oxidative stress status of refractory epileptic patients. Adv. Biomed. Res. 2016, 5, 36.

17. Hagberg, B.; Hamfelt, A.; Hansson, O. Epileptic Children with Disturbed Trytophan Metabolism Treated with Vitamin B6. Lancet 1964, 1, 145. [CrossRef]

18. Hansson, O.; Hagberg, B. Effect of pyridoxine treatment in children with epilepsy. Acta Soc. Med. Ups. 1968, $73,35-43$.

19. Jiao, F.Y.; Gao, D.Y.; Takuma, Y.; Wu, S.; Liu, Z.Y.; Zhang, X.K.; Lieu, N.S.; Ge, Z.L.; Chui, W.; Li, H.R.; et al. Randomized, controlled trial of high-dose intravenous pyridoxine in the treatment of recurrent seizures in children. Pediatr. Neurol. 1997, 17, 54-57. [CrossRef]

20. Wang, H.S.; Kuo, M.F. Vitamin B6 related epilepsy during childhood. Chang Gung Med. J. 2007, 30, $396-401$.

21. Winesett, S.P.; Bessone, S.K.; Kossoff, E.H. The ketogenic diet in pharmacoresistant childhood epilepsy. Expert Rev. Neurother. 2015, 15, 621-628. [CrossRef] [PubMed]

22. Liu, H.; Yang, Y.; Wang, Y.; Tang, H.; Zhang, F.; Zhang, Y.; Zhao, Y. Ketogenic diet for treatment of intractable epilepsy in adults: A meta-analysis of observational studies. Epilepsia Open 2018, 3, 9-17. [CrossRef] [PubMed]

23. Fisher, R.S.; Cross, J.H.; French, J.A.; Higurashi, N.; Hirsch, E.; Jansen, F.E.; Lagae, L.; Moshe, S.L.; Peltola, J.; Roulet Perez, E.; et al. Operational classification of seizure types by the International League Against Epilepsy: Position Paper of the ILAE Commission for Classification and Terminology. Epilepsia 2017, 58, 522-530. [CrossRef] [PubMed]

24. Berg, A.T.; Berkovic, S.F.; Brodie, M.J.; Buchhalter, J.; Cross, J.H.; van Emde Boas, W.; Engel, J.; French, J.; Glauser, T.A.; Mathern, G.W.; et al. Revised terminology and concepts for organization of seizures and epilepsies: Report of the ILAE Commission on Classification and Terminology, 2005-2009. Epilepsia 2010, 51, 676-685. [CrossRef] [PubMed]

25. Ran, X.; Li, J.; Shao, Q.; Chen, H.; Lin, Z.; Sun, Z.S.; Wu, J. EpilepsyGene: A genetic resource for genes and mutations related to epilepsy. Nucleic Acids Res. 2015, 43, D893-D899. [CrossRef] [PubMed]

26. Deng, H.; Xiu, X.; Song, Z. The molecular biology of genetic-based epilepsies. Mol. Neurobiol. 2014, 49, 352-367. [CrossRef] [PubMed]

27. Wei, F.; Yan, L.M.; Su, T.; He, N.; Lin, Z.J.; Wang, J.; Shi, Y.W.; Yi, Y.H.; Liao, W.P. Ion Channel Genes and Epilepsy: Functional Alteration, Pathogenic Potential, and Mechanism of Epilepsy. Neurosci. Bull. 2017, 33, 455-477. [CrossRef]

28. Scharfman, H.E. The neurobiology of epilepsy. Curr. Neurol. Neurosci. Rep. 2007, 7, 348-354. [CrossRef]

29. El Achkar, C.M.; Olson, H.E.; Poduri, A.; Pearl, P.L. The genetics of the epilepsies. Curr. Neurol. Neurosci. Rep. 2015, 15, 39. [CrossRef] 
30. Wang, J.; Lin, Z.J.; Liu, L.; Xu, H.Q.; Shi, Y.W.; Yi, Y.H.; He, N.; Liao, W.P. Epilepsy-associated genes. Seizure 2017, 44, 11-20. [CrossRef]

31. Wolfart, J.; Laker, D. Homeostasis or channelopathy? Acquired cell type-specific ion channel changes in temporal lobe epilepsy and their antiepileptic potential. Front. Physiol. 2015, 6, 168. [CrossRef]

32. Ogiwara, I.; Ito, K.; Sawaishi, Y.; Osaka, H.; Mazaki, E.; Inoue, I.; Montal, M.; Hashikawa, T.; Shike, T.; Fujiwara, T.; et al. De novo mutations of voltage-gated sodium channel alphaII gene SCN2A in intractable epilepsies. Neurology 2009, 73, 1046-1053. [CrossRef] [PubMed]

33. Estacion, M.; Gasser, A.; Dib-Hajj, S.D.; Waxman, S.G. A sodium channel mutation linked to epilepsy increases ramp and persistent current of Nav1.3 and induces hyperexcitability in hippocampal neurons. Exp. Neurol. 2010, 224, 362-368. [CrossRef] [PubMed]

34. Veeramah, K.R.; O’Brien, J.E.; Meisler, M.H.; Cheng, X.; Dib-Hajj, S.D.; Waxman, S.G.; Talwar, D.; Girirajan, S.; Eichler, E.E.; Restifo, L.L.; et al. De novo pathogenic SCN8A mutation identified by whole-genome sequencing of a family quartet affected by infantile epileptic encephalopathy and SUDEP. Am. J. Hum. Genet. 2012, 90, 502-510. [CrossRef] [PubMed]

35. Audenaert, D.; Claes, L.; Ceulemans, B.; Lofgren, A.; Van Broeckhoven, C.; De Jonghe, P. A deletion in SCN1B is associated with febrile seizures and early-onset absence epilepsy. Neurology 2003, 61, 854-856. [CrossRef] [PubMed]

36. Yu, F.H.; Mantegazza, M.; Westenbroek, R.E.; Robbins, C.A.; Kalume, F.; Burton, K.A.; Spain, W.J.; McKnight, G.S.; Scheuer, T.; Catterall, W.A. Reduced sodium current in GABAergic interneurons in a mouse model of severe myoclonic epilepsy in infancy. Nat. Neurosci. 2006, 9, 1142-1149. [CrossRef] [PubMed]

37. Martin, M.S.; Dutt, K.; Papale, L.A.; Dube, C.M.; Dutton, S.B.; de Haan, G.; Shankar, A.; Tufik, S.; Meisler, M.H.; Baram, T.Z.; et al. Altered function of the SCN1A voltage-gated sodium channel leads to gamma-aminobutyric acid-ergic (GABAergic) interneuron abnormalities. J. Biol. Chem. 2010, 285, 9823-9834. [CrossRef]

38. Papale, L.A.; Beyer, B.; Jones, J.M.; Sharkey, L.M.; Tufik, S.; Epstein, M.; Letts, V.A.; Meisler, M.H.; Frankel, W.N.; Escayg, A. Heterozygous mutations of the voltage-gated sodium channel SCN8A are associated with spike-wave discharges and absence epilepsy in mice. Hum. Mol. Genet. 2009, 18, 1633-1641. [CrossRef]

39. Singh, N.A.; Pappas, C.; Dahle, E.J.; Claes, L.R.F.; Pruess, T.H.; De Jonghe, P.; Thompson, J.; Dixon, M.; Gurnett, C.; Peiffer, A.; et al. A Role of SCN9A in Human Epilepsies, As a Cause of Febrile Seizures and As a Potential Modifier of Dravet Syndrome. PLoS Genet. 2009, 5, e1000649. [CrossRef]

40. Chen, C.; Westenbroek, R.E.; Xu, X.; Edwards, C.A.; Sorenson, D.R.; Chen, Y.; McEwen, D.P.; O'Malley, H.A.; Bharucha, V.; Meadows, L.S.; et al. Mice lacking sodium channel beta1 subunits display defects in neuronal excitability, sodium channel expression, and nodal architecture. J. Neurosci. 2004, 24, 4030-4042. [CrossRef]

41. Manolis, T.A.; Manolis, A.A.; Melita, H.; Manolis, A.S. Sudden unexpected death in epilepsy: The neuro-cardio-respiratory connection. Seizure 2019, 64, 65-73. [CrossRef]

42. Kalume, F.; Westenbroek, R.E.; Cheah, C.S.; Yu, F.H.; Oakley, J.C.; Scheuer, T.; Catterall, W.A. Sudden unexpected death in a mouse model of Dravet syndrome. J. Clin. Investig. 2013, 123, 1798-1808. [CrossRef] [PubMed]

43. Le Gal, F.; Korff, C.M.; Monso-Hinard, C.; Mund, M.T.; Morris, M.; Malafosse, A.; Schmitt-Mechelke, T. A case of SUDEP in a patient with Dravet syndrome with SCN1A mutation. Epilepsia 2010, 51, 1915-1918. [CrossRef] [PubMed]

44. Delogu, A.B.; Spinelli, A.; Battaglia, D.; Dravet, C.; De Nisco, A.; Saracino, A.; Romagnoli, C.; Lanza, G.A.; Crea, F. Electrical and autonomic cardiac function in patients with Dravet syndrome. Epilepsia 2011, 52, 55-58. [CrossRef] [PubMed]

45. Wagnon, J.L.; Korn, M.J.; Parent, R.; Tarpey, T.A.; Jones, J.M.; Hammer, M.F.; Murphy, G.G.; Parent, J.M.; Meisler, M.H. Convulsive seizures and SUDEP in a mouse model of SCN8A epileptic encephalopathy. Hum. Mol. Genet. 2015, 24, 506-515. [CrossRef] [PubMed]

46. Singh, N.A.; Westenskow, P.; Charlier, C.; Pappas, C.; Leslie, J.; Dillon, J.; Anderson, V.E.; Sanguinetti, M.C.; Leppert, M.F.; Consortium, B.P. KCNQ2 and KCNQ3 potassium channel genes in benign familial neonatal convulsions: Expansion of the functional and mutation spectrum. Brain 2003, 126, 2726-2737. [CrossRef] 
47. Peters, H.C.; Hu, H.; Pongs, O.; Storm, J.F.; Isbrandt, D. Conditional transgenic suppression of M channels in mouse brain reveals functions in neuronal excitability, resonance and behavior. Nat. Neurosci. 2005, 8, 51-60. [CrossRef] [PubMed]

48. Reid, C.A.; Berkovic, S.F.; Petrou, S. Mechanisms of human inherited epilepsies. Prog. Neurobiol. 2009, 87, 41-57. [CrossRef]

49. Heron, S.E.; Phillips, H.A.; Mulley, J.C.; Mazarib, A.; Neufeld, M.Y.; Berkovic, S.F.; Scheffer, I.E. Genetic variation of CACNA1H in idiopathic generalized epilepsy. Ann. Neurol. 2004, 55, 595-596. [CrossRef]

50. Becker, A.J.; Pitsch, J.; Sochivko, D.; Opitz, T.; Staniek, M.; Chen, C.C.; Campbell, K.P.; Schoch, S.; Yaari, Y.; Beck, H. Transcriptional upregulation of Cav3.2 mediates epileptogenesis in the pilocarpine model of epilepsy. J. Neurosci. 2008, 28, 13341-13353. [CrossRef]

51. Su, H.; Sochivko, D.; Becker, A.; Chen, J.; Jiang, Y.; Yaari, Y.; Beck, H. Upregulation of a T-type Ca2+ channel causes a long-lasting modification of neuronal firing mode after status epilepticus. J. Neurosci. 2002, 22, 3645-3655. [CrossRef]

52. Sanabria, E.R.; Su, H.; Yaari, Y. Initiation of network bursts by Ca2+-dependent intrinsic bursting in the rat pilocarpine model of temporal lobe epilepsy. J. Physiol. 2001, 532, 205-216. [CrossRef] [PubMed]

53. Meldrum, B. Physiological changes during prolonged seizures and epileptic brain damage. Neuropadiatrie 1978, 9, 203-212. [CrossRef] [PubMed]

54. Bernard, C.; Cossart, R.; Hirsch, J.C.; Esclapez, M.; Ben-Ari, Y. What is GABAergic inhibition? How is it modified in epilepsy? Epilepsia 2000, 41, S90-S95. [CrossRef] [PubMed]

55. Irier, H.A.; Shaw, R.; Lau, A.; Feng, Y.; Dingledine, R. Translational regulation of GluR2 mRNAs in rat hippocampus by alternative 3' untranslated regions. J. Neurochem. 2009, 109, 584-594. [CrossRef] [PubMed]

56. Rogawski, M.A. AMPA receptors as a molecular target in epilepsy therapy. Acta Neurol. Scand. 2013, 127, 9-18. [CrossRef] [PubMed]

57. Sperk, G.; Drexel, M.; Pirker, S. Neuronal plasticity in animal models and the epileptic human hippocampus. Epilepsia 2009, 50, 29-31. [CrossRef]

58. Turrens, J.F. Mitochondrial formation of reactive oxygen species. J. Physiol. 2003, 552, 335-344. [CrossRef]

59. Pearson-Smith, J.N.; Patel, M. Metabolic Dysfunction and Oxidative Stress in Epilepsy. Int. J. Mol. Sci. 2017, 18, 2365. [CrossRef]

60. Shin, E.J.; Jeong, J.H.; Chung, Y.H.; Kim, W.K.; Ko, K.H.; Bach, J.H.; Hong, J.S.; Yoneda, Y.; Kim, H.C. Role of oxidative stress in epileptic seizures. Neurochem. Int. 2011, 59, 122-137. [CrossRef]

61. Stadtman, E.R. Protein oxidation in aging and age-related diseases. Ann. N. Y. Acad. Sci. 2001, 928, $22-38$. [CrossRef]

62. Wong-Ekkabut, J.; Xu, Z.; Triampo, W.; Tang, I.M.; Tieleman, D.P.; Monticelli, L. Effect of lipid peroxidation on the properties of lipid bilayers: A molecular dynamics study. Biophys. J. 2007, 93, 4225-4236. [CrossRef] [PubMed]

63. Silvestri, G.; Moraes, C.T.; Shanske, S.; Oh, S.J.; DiMauro, S. A new mtDNA mutation in the tRNA(Lys) gene associated with myoclonic epilepsy and ragged-red fibers (MERRF). Am. J. Hum. Genet. 1992, 51, 1213-1217. [PubMed]

64. Ruhoy, I.S.; Saneto, R.P. The genetics of Leigh syndrome and its implications for clinical practice and risk management. Appl. Clin. Genet. 2014, 7, 221-234. [PubMed]

65. Wu, S.B.; Ma, Y.S.; Wu, Y.T.; Chen, Y.C.; Wei, Y.H. Mitochondrial DNA mutation-elicited oxidative stress, oxidative damage, and altered gene expression in cultured cells of patients with MERRF syndrome. Mol. Neurobiol. 2010, 41, 256-266. [CrossRef] [PubMed]

66. Wojtala, A.; Karkucinska-Wieckowska, A.; Sardao, V.A.; Szczepanowska, J.; Kowalski, P.; Pronicki, M.; Duszynski, J.; Wieckowski, M.R. Modulation of mitochondrial dysfunction-related oxidative stress in fibroblasts of patients with Leigh syndrome by inhibition of prooxidative p66Shc pathway. Mitochondrion 2017, 37, 62-79. [CrossRef] [PubMed]

67. Brini, M.; Pinton, P.; King, M.P.; Davidson, M.; Schon, E.A.; Rizzuto, R. A calcium signaling defect in the pathogenesis of a mitochondrial DNA inherited oxidative phosphorylation deficiency. Nat. Med. 1999, 5, 951-954. [CrossRef]

68. Kudin, A.P.; Baron, G.; Zsurka, G.; Hampel, K.G.; Elger, C.E.; Grote, A.; Weber, Y.; Lerche, H.; Thiele, H.; Nurnberg, P.; et al. Homozygous mutation in TXNRD1 is associated with genetic generalized epilepsy. Free Radic. Biol. Med. 2017, 106, 270-277. [CrossRef] 
69. Roma-Mateo, C.; Aguado, C.; Garcia-Gimenez, J.L.; Knecht, E.; Sanz, P.; Pallardo, F.V. Oxidative stress, a new hallmark in the pathophysiology of Lafora progressive myoclonus epilepsy. Free Radic. Biol. Med. 2015, 88, 30-41. [CrossRef]

70. Roma-Mateo, C.; Aguado, C.; Garcia-Gimenez, J.L.; Ibanez-Cabellos, J.S.; Seco-Cervera, M.; Pallardo, F.V.; Knecht, E.; Sanz, P. Increased oxidative stress and impaired antioxidant response in Lafora disease. Mol. Neurobiol. 2015, 51, 932-946. [CrossRef]

71. Kovac, S.; Dinkova Kostova, A.T.; Herrmann, A.M.; Melzer, N.; Meuth, S.G.; Gorji, A. Metabolic and Homeostatic Changes in Seizures and Acquired Epilepsy-Mitochondria, Calcium Dynamics and Reactive Oxygen Species. Int. J. Mol. Sci. 2017, 18, 1935. [CrossRef]

72. Kunz, W.S.; Kudin, A.P.; Vielhaber, S.; Blumcke, I.; Zuschratter, W.; Schramm, J.; Beck, H.; Elger, C.E. Mitochondrial complex I deficiency in the epileptic focus of patients with temporal lobe epilepsy. Ann. Neurol. 2000, 48, 766-773. [CrossRef]

73. Lopez, J.; Gonzalez, M.E.; Lorigados, L.; Morales, L.; Riveron, G.; Bauza, J.Y. Oxidative stress markers in surgically treated patients with refractory epilepsy. Clin. Biochem. 2007, 40, 292-298. [CrossRef] [PubMed]

74. Pecorelli, A.; Natrella, F.; Belmonte, G.; Miracco, C.; Cervellati, F.; Ciccoli, L.; Mariottini, A.; Rocchi, R.; Vatti, G.; Bua, A.; et al. NADPH oxidase activation and 4-hydroxy-2-nonenal/aquaporin-4 adducts as possible new players in oxidative neuronal damage presents in drug-resistant epilepsy. Biochim. Biophys. Acta 2015, 1852, 507-519. [CrossRef] [PubMed]

75. Rumia, J.; Marmol, F.; Sanchez, J.; Gimenez-Crouseilles, J.; Carreno, M.; Bargallo, N.; Boget, T.; Pintor, L.; Setoain, X.; Donaire, A.; et al. Oxidative stress markers in the neocortex of drug-resistant epilepsy patients submitted to epilepsy surgery. Epilepsy Res. 2013, 107, 75-81. [CrossRef]

76. Ristic, A.J.; Savic, D.; Sokic, D.; Bogdanovic Pristov, J.; Nestorov, J.; Bascarevic, V.; Raicevic, S.; Savic, S.; Spasojevic, I. Hippocampal antioxidative system in mesial temporal lobe epilepsy. Epilepsia 2015, 56, 789-799. [CrossRef] [PubMed]

77. Yuzbasioglu, A.; Karatas, H.; Gursoy-Ozdemir, Y.; Saygi, S.; Akalan, N.; Soylemezoglu, F.; Dalkara, T.; Kocaefe, Y.C.; Ozguc, M. Changes in the expression of selenoproteins in mesial temporal lobe epilepsy patients. Cell. Mol. Neurobiol. 2009, 29, 1223-1231. [CrossRef]

78. Liang, L.P.; Ho, Y.S.; Patel, M. Mitochondrial superoxide production in kainate-induced hippocampal damage. Neuroscience 2000, 101, 563-570. [CrossRef]

79. Patel, M.; Liang, L.P.; Roberts, L.J., 2nd. Enhanced hippocampal F2-isoprostane formation following kainate-induced seizures. J. Neurochem. 2001, 79, 1065-1069. [CrossRef]

80. Furukawa, A.; Kawamoto, Y.; Chiba, Y.; Takei, S.; Hasegawa-Ishii, S.; Kawamura, N.; Yoshikawa, K.; Hosokawa, M.; Oikawa, S.; Kato, M.; et al. Proteomic identification of hippocampal proteins vulnerable to oxidative stress in excitotoxin-induced acute neuronal injury. Neurobiol. Dis. 2011, 43, 706-714. [CrossRef]

81. Ryan, K.; Backos, D.S.; Reigan, P.; Patel, M. Post-translational oxidative modification and inactivation of mitochondrial complex I in epileptogenesis. J. Neurosci. 2012, 32, 11250-11258. [CrossRef]

82. Jarrett, S.G.; Liang, L.P.; Hellier, J.L.; Staley, K.J.; Patel, M. Mitochondrial DNA damage and impaired base excision repair during epileptogenesis. Neurobiol. Dis. 2008, 30, 130-138. [CrossRef] [PubMed]

83. Dal-Pizzol, F.; Klamt, F.; Vianna, M.M.; Schroder, N.; Quevedo, J.; Benfato, M.S.; Moreira, J.C.; Walz, R. Lipid peroxidation in hippocampus early and late after status epilepticus induced by pilocarpine or kainic acid in Wistar rats. Neurosci. Lett. 2000, 291, 179-182. [CrossRef]

84. Liang, L.P.; Patel, M. Mitochondrial oxidative stress and increased seizure susceptibility in Sod2(-/+) mice. Free Radic. Biol. Med. 2004, 36, 542-554. [CrossRef] [PubMed]

85. Melov, S.; Coskun, P.; Patel, M.; Tuinstra, R.; Cottrell, B.; Jun, A.S.; Zastawny, T.H.; Dizdaroglu, M.; Goodman, S.I.; Huang, T.T.; et al. Mitochondrial disease in superoxide dismutase 2 mutant mice. Proc. Natl. Acad. Sci. USA 1999, 96, 846-851. [CrossRef] [PubMed]

86. Virta, M.; Hurme, M.; Helminen, M. Increased frequency of interleukin-1beta (-511) allele 2 in febrile seizures. Pediatr. Neurol. 2002, 26, 192-195. [CrossRef]

87. Al Morshedy, S.; Elsaadany, H.F.; Ibrahim, H.E.; Sherif, A.M.; Farghaly, M.A.; Allah, M.A.; Abouzeid, H.; Elashkar, S.S.; Hamed, M.E.; Fathy, M.M.; et al. Interleukin-1beta and interleukin-1receptor antagonist polymorphisms in Egyptian children with febrile seizures: A case-control study. Medicine (Baltimore) 2017, 96, e6370. [CrossRef] 
88. Devinsky, O.; Vezzani, A.; Najjar, S.; De Lanerolle, N.C.; Rogawski, M.A. Glia and epilepsy: Excitability and inflammation. Trends Neurosci. 2013, 36, 174-184. [CrossRef]

89. Webster, K.M.; Sun, M.; Crack, P.; O’Brien, T.J.; Shultz, S.R.; Semple, B.D. Inflammation in epileptogenesis after traumatic brain injury. J. Neuroinflamm. 2017, 14, 10. [CrossRef]

90. Van Vliet, E.A.; Aronica, E.; Vezzani, A.; Ravizza, T. Review: Neuroinflammatory pathways as treatment targets and biomarker candidates in epilepsy: Emerging evidence from preclinical and clinical studies. Neuropathol. Appl. Neurobiol. 2018, 44, 91-111. [CrossRef]

91. Marchi, N.; Fan, Q.; Ghosh, C.; Fazio, V.; Bertolini, F.; Betto, G.; Batra, A.; Carlton, E.; Najm, I.; Granata, T.; et al. Antagonism of peripheral inflammation reduces the severity of status epilepticus. Neurobiol. Dis. 2009, 33, 171-181. [CrossRef]

92. Zhao, H.; Zhu, C.; Huang, D. Microglial activation: An important process in the onset of epilepsy. Am. J. Transl. Res. 2018, 10, 2877-2889. [PubMed]

93. Paudel, Y.N.; Semple, B.D.; Jones, N.C.; Othman, I.; Shaikh, M.F. High mobility group box 1 (HMGB1) as a novel frontier in epileptogenesis: From pathogenesis to therapeutic approaches. J. Neurochem. 2019, 149. [CrossRef] [PubMed]

94. Maroso, M.; Balosso, S.; Ravizza, T.; Liu, J.; Aronica, E.; Iyer, A.M.; Rossetti, C.; Molteni, M.; Casalgrandi, M.; Manfredi, A.A.; et al. Toll-like receptor 4 and high-mobility group box-1 are involved in ictogenesis and can be targeted to reduce seizures. Nat. Med. 2010, 16, 413-491. [CrossRef] [PubMed]

95. De Sarro, G.; Russo, E.; Ferreri, G.; Giuseppe, B.; Flocco, M.A.; Di Paola, E.D.; De Sarro, A. Seizure susceptibility to various convulsant stimuli of knockout interleukin-6 mice. Pharmacol. Biochem. Behav. 2004, 77, 761-766. [CrossRef] [PubMed]

96. Peltola, J.; Hurme, M.; Miettinen, A.; Keranen, T. Elevated levels of interleukin- 6 may occur in cerebrospinal fluid from patients with recent epileptic seizures. Epilepsy Res. 1998, 31, 129-133. [CrossRef]

97. Riazi, K.; Galic, M.A.; Kuzmiski, J.B.; Ho, W.; Sharkey, K.A.; Pittman, Q.J. Microglial activation and TNF alpha production mediate altered CNS excitability following peripheral inflammation. Proc. Natl. Acad. Sci. USA 2008, 105, 17151-17156. [CrossRef] [PubMed]

98. Weinberg, M.S.; Blake, B.L.; McCown, T.J. Opposing actions of hippocampus TNF alpha receptors on limbic seizure susceptibility. Exp. Neurol. 2013, 247, 429-437. [CrossRef] [PubMed]

99. Balosso, S.; Ravizza, T.; Perego, C.; Peschon, J.; Campbell, I.L.; De Simoni, M.G.; Vezzani, A. Tumor necrosis factor-alpha inhibits seizures in mice via p75 receptors. Ann. Neurol. 2005, 57, 804-812. [CrossRef] [PubMed]

100. Taha, A.Y.; Burnham, W.M.; Auvin, S. Polyunsaturated fatty acids and epilepsy. Epilepsia 2010, 51, 1348-1358. [CrossRef] [PubMed]

101. Pourmasoumi, M.; Vosoughi, N.; Derakhshandeh-Rishehri, S.M.; Assarroudi, M.; Heidari-Beni, M. Association of Omega-3 Fatty Acid and Epileptic Seizure in Epileptic Patients: A Systematic Review. Int. J. Prev. Med. 2018, 9, 36. [PubMed]

102. Lund, E.K.; Harvey, L.J.; Ladha, S.; Clark, D.C.; Johnson, I.T. Effects of dietary fish oil supplementation on the phospholipid composition and fluidity of cell membranes from human volunteers. Ann. Nutr. Metab. 1999, 43, 290-300. [CrossRef] [PubMed]

103. Voskuyl, R.A.; Vreugdenhil, M.; Kang, J.X.; Leaf, A. Anticonvulsant effect of polyunsaturated fatty acids in rats, using the cortical stimulation model. Eur. J. Pharmacol. 1998, 341, 145-152. [CrossRef]

104. Taha, A.Y.; Zahid, T.; Epps, T.; Trepanier, M.O.; Burnham, W.M.; Bazinet, R.P.; Zhang, L. Selective reduction of excitatory hippocampal sharp waves by docosahexaenoic acid and its methyl ester analog ex-vivo. Brain Res. 2013, 1537, 9-17. [CrossRef] [PubMed]

105. Calder, P.C.; Yaqoob, P. Omega-3 (n-3) fatty acids, cardiovascular disease and stability of atherosclerotic plaques. Cell. Mol. Biol. 2010, 56, 28-37. [PubMed]

106. Puri, B.K.; Koepp, M.J.; Holmes, J.; Hamilton, G.; Yuen, A.W. A 31-phosphorus neurospectroscopy study of omega-3 long-chain polyunsaturated fatty acid intervention with eicosapentaenoic acid and docosahexaenoic acid in patients with chronic refractory epilepsy. Prostaglandins Leukot. Essent. Fatty Acids 2007, 77, 105-107. [CrossRef] [PubMed]

107. Dahlin, M.; Hjelte, L.; Nilsson, S.; Amark, P. Plasma phospholipid fatty acids are influenced by a ketogenic diet enriched with n-3 fatty acids in children with epilepsy. Epilepsy Res. 2007, 73, 199-207. [CrossRef]

108. Bromfield, E.; Dworetzky, B.; Hurwitz, S.; Eluri, Z.; Lane, L.; Replansky, S.; Mostofsky, D. A randomized trial of polyunsaturated fatty acids for refractory epilepsy. Epilepsy Behav. 2008, 12, 187-190. [CrossRef] 
109. Yuen, A.W.; Flugel, D.; Poepel, A.; Bell, G.S.; Peacock, J.L.; Sander, J.W. Non-randomized open trial of eicosapentaenoic acid (EPA), an omega-3 fatty acid, in ten people with chronic epilepsy. Epilepsy Behav. 2012, 23, 370-372. [CrossRef]

110. Scorza, F.A.; Cysneiros, R.M.; Arida, R.M.; Terra, V.C.; Machado, H.R.; Rabello, G.M.M.; Albuquerque, M.; Cavalheiro, E.A. Fish consumption, contaminants and sudden unexpected death in epilepsy: Many more benefits than risks. Braz. J. Biol. 2010, 70, 665-670. [CrossRef]

111. Saxena, A.; Jones, L.; Shankar, R.; McLean, B.; Newman, C.G.J.; Hamandi, K. Sudden unexpected death in epilepsy in children: A focused review of incidence and risk factors. J. Neurol. Neurosurg. Psychiatry 2018, 89, 1064-1070. [CrossRef]

112. Tomson, T.; Walczak, T.; Sillanpaa, M.; Sander, J.W. Sudden unexpected death in epilepsy: A review of incidence and risk factors. Epilepsia 2005, 46, 54-61. [CrossRef] [PubMed]

113. Scorza, F.A.; Cysneiros, R.M.; Arida, R.M.; Terra-Bustamante, V.C.; de Albuquerque, M.; Cavalheiro, E.A. The other side of the coin: Beneficiary effect of omega-3 fatty acids in sudden unexpected death in epilepsy. Epilepsy Behav. 2008, 13, 279-283. [CrossRef] [PubMed]

114. Yuen, A.W.C.; Sander, J.W. Is omega-3 fatty acid deficiency a factor contributing to refractory seizures and SUDEP? A hypothesis. Seizure 2004, 13, 104-107. [CrossRef]

115. Scorza, C.A.; Cavalheiro, E.A.; Calderazzo, L.; de Almeida, A.C.G.; Scorza, F.A. Chew on this: Sardines are still a healthy choice against SUDEP. Epilepsy Behav. 2014, 41, 21-22. [CrossRef] [PubMed]

116. Cysneiros, R.M.; Arida, R.M.; Terra, V.C.; Sonoda, E.Y.; Cavalheiro, E.A.; Scorza, F.A. To sushi or not to sushi: Can people with epilepsy have sushi from time to time? Epilepsy Behav. 2009, 16, 565-566. [CrossRef] [PubMed]

117. Scorza, F.A.; Scorza, C.A.; Cavalheiro, E.A. Omega-3 fatty acids and SUDEP prevention. Lancet Neurol. 2016, 15, 1303. [CrossRef]

118. Taha, A.Y.; Trepanier, M.O.; Ciobanu, F.A.; Taha, N.M.; Ahmed, M.; Zeng, Q.; Cheuk, W.I.; Ip, B.; Filo, E.; Scott, B.W.; et al. A minimum of 3 months of dietary fish oil supplementation is required to raise amygdaloid afterdischarge seizure thresholds in rats-Implications for treating complex partial seizures. Epilepsy Behav. 2013, 27, 49-58. [CrossRef]

119. Trepanier, M.O.; Taha, A.Y.; Mantha, R.L.; Ciobanu, F.A.; Zeng, Q.H.; Tchkhartichvili, G.M.; Domenichiello, A.F.; Bazinet, R.P.; Burnham, W.M. Increases in seizure latencies induced by subcutaneous docosahexaenoic acid are lost at higher doses. Epilepsy Res. 2012, 99, 225-232. [CrossRef]

120. Flores-Mancilla, L.E.; Hernandez-Gonzalez, M.; Guevara, M.A.; Benavides-Haro, D.E.; Martinez-Arteaga, P. Long-term fish oil supplementation attenuates seizure activity in the amygdala induced by 3-mercaptopropionic acid in adult male rats. Epilepsy Behav. 2014, 33, 126-134. [CrossRef]

121. Bandero, C.R.; Salvadori, M.G.; Gomes, A.T.; Dal Ri, N.M.; Furian, A.F.; Oliveira, M.S.; Rambo, L.M.; Scorza, F.A.; Cysneiros, R.M.; Emanuelli, T.; et al. Fish oil attenuates methylmalonate-induced seizures. Epilepsy Res. 2013, 105, 69-76. [CrossRef]

122. Abdel-Wahab, B.A.; Al-Qahtani, J.M.; El-Safty, S.A. Omega-3 polyunsaturated fatty acids in large doses attenuate seizures, cognitive impairment, and hippocampal oxidative DNA damage in young kindled rats. Neurosci. Lett. 2015, 584, 173-177. [CrossRef] [PubMed]

123. Trepanier, M.O.; Lim, J.; Lai, T.K.; Cho, H.J.; Domenichiello, A.F.; Chen, C.T.; Taha, A.Y.; Bazinet, R.P.; Burnham, W.M. Intraperitoneal administration of docosahexaenoic acid for 14days increases serum unesterified DHA and seizure latency in the maximal pentylenetetrazol model. Epilepsy Behav. 2014, 33, 138-143. [CrossRef] [PubMed]

124. Ishihara, Y.; Itoh, K.; Tanaka, M.; Tsuji, M.; Kawamoto, T.; Kawato, S.; Vogel, C.F.A.; Yamazaki, T. Potentiation of 17 beta-estradiol synthesis in the brain and elongation of seizure latency through dietary supplementation with docosahexaenoic acid. Sci. Rep. 2017, 7, 6268. [CrossRef] [PubMed]

125. Vreugdenhil, M.; Bruehl, C.; Voskuyl, R.A.; Kang, J.X.; Leaf, A.; Wadman, W.J. Polyunsaturated fatty acids modulate sodium and calcium currents in CA1 neurons. Proc. Natl. Acad. Sci. USA 1996, 93, 12559-12563. [CrossRef] [PubMed]

126. Hong, M.P.; Kim, H.I.; Shin, Y.K.; Lee, C.S.; Park, M.; Song, J.H. Effects of free fatty acids on sodium currents in rat dorsal root ganglion neurons. Brain Res. 2004, 1008, 81-91. [CrossRef] [PubMed]

127. Liin, S.I.; Karlsson, U.; Bentzen, B.H.; Schmitt, N.; Elinder, F. Polyunsaturated fatty acids are potent openers of human M-channels expressed in Xenopus laevis oocytes. Acta Physiol. 2016, 218, 28-37. [CrossRef] [PubMed] 
128. Hamano, H.; Nabekura, J.; Nishikawa, M.; Ogawa, T. Docosahexaenoic acid reduces GABA response in substantia nigra neuron of rat. J. Neurophysiol. 1996, 75, 1264-1270. [CrossRef] [PubMed]

129. Nabekura, J.; Noguchi, K.; Witt, M.R.; Nielsen, M.; Akaike, N. Functional modulation of human recombinant gamma-aminobutyric acid type A receptor by docosahexaenoic acid. J. Biol. Chem. 1998, 273, 11056-11061. [CrossRef]

130. Sogaard, R.; Werge, T.M.; Bertelsen, C.; Lundbye, C.; Madsen, K.L.; Nielsen, C.H.; Lundbaek, J.A. GABA(A) receptor function is regulated by lipid bilayer elasticity. Biochemistry 2006, 45, 13118-13129. [CrossRef]

131. Ferrari, D.; Cysneiros, R.M.; Scorza, C.A.; Arida, R.M.; Cavalheiro, E.A.; de Almeida, A.C.; Scorza, F.A. Neuroprotective activity of omega-3 fatty acids against epilepsy-induced hippocampal damage: Quantification with immunohistochemical for calcium-binding proteins. Epilepsy Behav. 2008, 13, 36-42. [CrossRef]

132. Cysneiros, R.M.; Ferrari, D.; Arida, R.M.; Terra, V.C.; de Almeida, A.C.; Cavalheiro, E.A.; Scorza, F.A. Qualitative analysis of hippocampal plastic changes in rats with epilepsy supplemented with oral omega-3 fatty acids. Epilepsy Behav. 2010, 17, 33-38. [CrossRef] [PubMed]

133. Liu, S.H.; Chang, C.D.; Chen, P.H.; Su, J.R.; Chen, C.C.; Chaung, H.C. Docosahexaenoic acid and phosphatidylserine supplementations improve antioxidant activities and cognitive functions of the developing brain on pentylenetetrazol-induced seizure model. Brain Res. 2012, 1451, 19-26. [CrossRef] [PubMed]

134. Nejm, M.B.; Haidar, A.A.; Marques, M.J.; Hirata, A.E.; Nogueira, F.N.; Cavalheiro, E.A.; Scorza, F.A.; Cysneiros, R.M. Fish oil provides protection against the oxidative stress in pilocarpine model of epilepsy. Metab. Brain Dis. 2015, 30, 903-909. [CrossRef] [PubMed]

135. Gouveia, T.L.; Vieira de Sousa, P.V.; de Almeida, S.S.; Nejm, M.B.; Vieira de Brito, J.M.; Cysneiros, R.M.; de Brito, M.V.; Salu, B.R.; Oliva, M.L.; Scorza, F.A.; et al. High serum levels of proinflammatory markers during epileptogenesis. Can omega-3 fatty acid administration reduce this process? Epilepsy Behav. 2015, 51, 300-305. [CrossRef] [PubMed]

136. NIH Office of Dietary Supplements. Vitamin D. Fact Sheet for Health Professionals. Available online: https://ods.od.nih.gov/factsheets/VitaminD-HealthProfessional/\#en11 (accessed on 9 November 2018).

137. Pendo, K.; DeGiorgio, C.M. Vitamin D3 for the Treatment of Epilepsy: Basic Mechanisms, Animal Models, and Clinical Trials. Front. Neurol. 2016, 7, 218. [CrossRef] [PubMed]

138. Eyles, D.W.; Burne, T.H.J.; McGrath, J.J. Vitamin D, effects on brain development, adult brain function and the links between low levels of vitamin D and neuropsychiatric disease. Front. Neuroendocrinol. 2013, 34, 47-64. [CrossRef] [PubMed]

139. Teagarden, D.L.; Meador, K.J.; Loring, D.W. Low vitamin D levels are common in patients with epilepsy. Epilepsy Res. 2014, 108, 1352-1356. [CrossRef] [PubMed]

140. Offermann, G.; Pinto, V.; Kruse, R. Antiepileptic drugs and vitamin D supplementation. Epilepsia 1979, 20, 3-15. [CrossRef] [PubMed]

141. Chaudhuri, J.R.; Mridula, K.R.; Rathnakishore, C.; Balaraju, B.; Bandaru, V.S. Association of 25-Hydroxyvitamin D Deficiency in Pediatric Epileptic Patients. Iran. J. Child Neurol. 2017, 11, 48-56.

142. Garcia, V.C.; Martini, L.A. Vitamin D and cardiovascular disease. Nutrients 2010, 2, 426-437. [CrossRef]

143. Scorza, F.A.; de Albuquerque, M.; Arida, R.M.; Terra, V.C.; Machado, H.R.; Cavalheiro, E.A. Benefits of sunlight: Vitamin D deficiency might increase the risk of sudden unexpected death in epilepsy. Med. Hypotheses 2010, 74, 158-161. [CrossRef] [PubMed]

144. Mann, M.C.; Exner, D.V.; Hemmelgarn, B.R.; Hanley, D.A.; Turin, T.C.; MacRae, J.M.; Wheeler, D.C.; Sola, D.Y.; Ramesh, S.; Ahmed, S.B. The VITAH Trial-Vitamin D Supplementation and Cardiac Autonomic Tone in Patients with End-Stage Kidney Disease on Hemodialysis: A Blinded, Randomized Controlled Trial. Nutrients 2016, 8, 608. [CrossRef] [PubMed]

145. Mann, M.C.; Hemmelgarn, B.R.; Exner, D.V.; Hanley, D.A.; Turin, T.C.; Wheeler, D.C.; Sola, D.Y.; Ellis, L.; Ahmed, S.B. Vitamin D supplementation is associated with stabilization of cardiac autonomic tone in $\operatorname{IgA}$ nephropathy. Hypertension 2015, 66, 4-6. [CrossRef] [PubMed]

146. Mann, M.C.; Exner, D.V.; Hemmelgarn, B.R.; Hanley, D.A.; Turin, T.C.; MacRae, J.M.; Ahmed, S.B. The VITAH trial VITamin D supplementation and cardiac Autonomic tone in Hemodialysis: A blinded, randomized controlled trial. BMC Nephrol. 2014, 15, 129. [CrossRef] [PubMed] 
147. Mann, M.C.; Exner, D.V.; Hemmelgarn, B.R.; Turin, T.C.; Sola, D.Y.; Ellis, L.; Ahmed, S.B. Vitamin D supplementation is associated with improved modulation of cardiac autonomic tone in healthy humans. Int. J. Cardiol. 2014, 172, 506-508. [CrossRef] [PubMed]

148. Novak, J.L.; Miller, P.R.; Markovic, D.; Meymandi, S.K.; DeGiorgio, C.M. Risk Assessment for Sudden Death in Epilepsy: The SUDEP-7 Inventory. Front. Neurol. 2015, 6, 252. [CrossRef]

149. DeGiorgio, C.M.; Miller, P.; Meymandi, S.; Chin, A.; Epps, J.; Gordon, S.; Gornbein, J.; Harper, R.M. RMSSD, a measure of vagus-mediated heart rate variability, is associated with risk factors for SUDEP: The SUDEP-7 Inventory. Epilepsy Behav. 2010, 19, 78-81. [CrossRef] [PubMed]

150. Siegel, A.; Malkowitz, L.; Moskovits, M.J.; Christakos, S. Administration of 1,25-dihydroxyvitamin D3 results in the elevation of hippocampal seizure threshold levels in rats. Brain Res. 1984, 298, 125-129. [CrossRef]

151. Abdel-Wahab, A.F.; Afify, M.A.; Mahfouz, A.M.; Shahzad, N.; Bamagous, G.A.; Al Ghamdi, S.S. Vitamin D enhances antiepileptic and cognitive effects of lamotrigine in pentylenetetrazole-kindled rats. Brain Res. 2017, 1673, 78-85. [CrossRef]

152. Kalueff, A.V.; Minasyan, A.; Tuohimaa, P. Anticonvulsant effects of 1,25-dihydroxyvitamin D in chemically induced seizures in mice. Brain Res. Bull. 2005, 67, 156-160. [CrossRef]

153. Borowicz, K.K.; Morawska, M.; Furmanek-Karwowska, K.; Luszczki, J.J.; Czuczwar, S.J. Cholecalciferol enhances the anticonvulsant effect of conventional antiepileptic drugs in the mouse model of maximal electroshock. Eur. J. Pharmacol. 2007, 573, 111-115. [CrossRef] [PubMed]

154. Kalueff, A.V.; Minasyan, A.; Keisala, T.; Kuuslahti, M.; Miettinen, S.; Tuohimaa, P. Increased severity of chemically induced seizures in mice with partially deleted Vitamin D receptor gene. Neurosci. Lett. 2006, 394, 69-73. [CrossRef] [PubMed]

155. Brewer, L.D.; Thibault, V.; Chen, K.C.; Langub, M.C.; Landfield, P.W.; Porter, N.M. Vitamin D hormone confers neuroprotection in parallel with downregulation of L-type calcium channel expression in hippocampal neurons. J. Neurosci. 2001, 21, 98-108. [CrossRef] [PubMed]

156. Zanatta, L.; Goulart, P.B.; Goncalves, R.; Pierozan, P.; Winkelmann-Duarte, E.C.; Woehl, V.M.; Pessoa-Pureur, R.; Silva, F.R.M.B.; Zamoner, A. 1 alpha,25-Dihydroxyvitamin D-3 mechanism of action: Modulation of L-type calcium channels leading to calcium uptake and intermediate filament phosphorylation in cerebral cortex of young rats. BBA Mol. Cell Res. 2012, 1823, 1708-1719.

157. Dursun, E.; Gezen-Ak, D.; Yilmazer, S. The Influence of Vitamin D Treatment on the Inducible Nitric Oxide Synthase (INOS) Expression in Primary Hippocampal Neurons. Noro. Psikiyatr. Ars. 2014, 51, 163-168. [CrossRef] [PubMed]

158. Lefebvre d'Hellencourt, C.; Montero-Menei, C.N.; Bernard, R.; Couez, D. Vitamin D3 inhibits proinflammatory cytokines and nitric oxide production by the EOC13 microglial cell line. J. Neurosci. Res. 2003, 71, 575-582. [CrossRef] [PubMed]

159. Bartels, L.E.; Jorgensen, S.P.; Agnholt, J.; Kelsen, J.; Hvas, C.L.; Dahlerup, J.F. 1,25-dihydroxyvitamin D3 and dexamethasone increase interleukin-10 production in CD4+ T cells from patients with Crohn's disease. Int. Immunopharmacol. 2007, 7, 1755-1764. [CrossRef] [PubMed]

160. Friedman, M. Chemistry, Nutrition, and Health-Promoting Properties of Hericium erinaceus (Lion's Mane) Mushroom Fruiting Bodies and Mycelia and Their Bioactive Compounds. J. Agric. Food Chem. 2015, 63, 7108-7123. [CrossRef] [PubMed]

161. Jang, H.J.; Kim, J.E.; Jeong, K.H.; Lim, S.C.; Kim, S.Y.; Cho, K.O. The Neuroprotective Effect of Hericium erinaceus Extracts in Mouse Hippocampus after Pilocarpine-Induced Status Epilepticus. Int. J. Mol. Sci. 2019, 20. [CrossRef] [PubMed]

162. NIH Office of Dietary Supplements. Vitamin E. Fact Sheet for Health Professionals. Available online: https://ods.od.nih.gov/factsheets/VitaminE-HealthProfessional/ (accessed on 17 August 2018).

163. Lloret, A.; Esteve, D.; Monllor, P.; Cervera-Ferri, A.; Lloret, A. The Effectiveness of Vitamin E Treatment in Alzheimer's Disease. Int. J. Mol. Sci. 2019, 20, 879. [CrossRef]

164. Sozen, E.; Demirel, T.; Ozer, N.K. Vitamin E: Regulatory role in the cardiovascular system. IUBMB Life 2019, 71,507-515. [CrossRef] [PubMed]

165. Uchida, D.; Takaki, A.; Adachi, T.; Okada, H. Beneficial and Paradoxical Roles of Anti-Oxidative Nutritional Support for Non-Alcoholic Fatty Liver Disease. Nutrients 2018, 10, 977. [CrossRef] 
166. Raju, G.B.; Behari, M.; Prasad, K.; Ahuja, G.K. Randomized, double-blind, placebo-controlled, clinical trial of D-alpha-tocopherol (vitamin E) as add-on therapy in uncontrolled epilepsy. Epilepsia 1994, 35, 368-372. [CrossRef] [PubMed]

167. Ayyildiz, M.; Yildirim, M.; Agar, E. The effects of vitamin E on penicillin-induced epileptiform activity in rats. Exp. Brain Res. 2006, 174, 109-113. [CrossRef]

168. Ambrogini, P.; Albertini, M.C.; Betti, M.; Galati, C.; Lattanzi, D.; Savelli, D.; Di Palma, M.; Saccomanno, S.; Bartolini, D.; Torquato, P.; et al. Neurobiological Correlates of Alpha-Tocopherol Antiepileptogenic Effects and MicroRNA Expression Modulation in a Rat Model of Kainate-Induced Seizures. Mol. Neurobiol. 2018, 55, 7822-7838. [CrossRef] [PubMed]

169. Levy, S.L.; Burnham, W.M.; Bishai, A.; Hwang, P.A. The anticonvulsant effects of vitamin E: A further evaluation. Can. J. Neurol. Sci. 1992, 19, 201-203. [CrossRef] [PubMed]

170. Levy, S.L.; Burnham, W.M.; Hwang, P.A. An evaluation of the anticonvulsant effects of vitamin E. Epilepsy Res. 1990, 6, 12-17. [CrossRef]

171. Ribeiro, M.C.; de Avila, D.S.; Schneider, C.Y.; Hermes, F.S.; Furian, A.F.; Oliveira, M.S.; Rubin, M.A.; Lehmann, M.; Krieglstein, J.; Mello, C.F. alpha-Tocopherol protects against pentylenetetrazol- and methylmalonate-induced convulsions. Epilepsy Res. 2005, 66, 185-194. [CrossRef]

172. Ambrogini, P.; Minelli, A.; Galati, C.; Betti, M.; Lattanzi, D.; Ciffolilli, S.; Piroddi, M.; Galli, F.; Cuppini, R. Post-seizure alpha-tocopherol treatment decreases neuroinflammation and neuronal degeneration induced by status epilepticus in rat hippocampus. Mol. Neurobiol. 2014, 50, 246-256. [CrossRef]

173. Zakharova, I.O.; Sokolova, T.V.; Vlasova, Y.A.; Bayunova, L.V.; Rychkova, M.P.; Avrova, N.F. alpha-Tocopherol at Nanomolar Concentration Protects Cortical Neurons against Oxidative Stress. Int. J. Mol. Sci. 2017, 18, 216. [CrossRef]

174. Ferri, P.; Cecchini, T.; Ambrogini, P.; Betti, M.; Cuppini, R.; Del Grande, P.; Ciaroni, S. alpha-Tocopherol affects neuronal plasticity in adult rat dentate gyrus: The possible role of PKCdelta. J. Neurobiol. 2006, 66, 793-810. [CrossRef] [PubMed]

175. Brodie, C.; Bogi, K.; Acs, P.; Lorenzo, P.S.; Baskin, L.; Blumberg, P.M. Protein kinase C delta (PKCdelta) inhibits the expression of glutamine synthetase in glial cells via the PKCdelta regulatory domain and its tyrosine phosphorylation. J. Biol. Chem. 1998, 273, 30713-30718. [CrossRef] [PubMed]

176. Osakada, F.; Hashino, A.; Kume, T.; Katsuki, H.; Kaneko, S.; Akaike, A. Neuroprotective effects of alpha-tocopherol on oxidative stress in rat striatal cultures. Eur. J. Pharmacol. 2003, 465, 15-22. [CrossRef]

177. Betti, M.; Minelli, A.; Ambrogini, P.; Ciuffoli, S.; Viola, V.; Galli, F.; Canonico, B.; Lattanzi, D.; Colombo, E.; Sestili, P.; et al. Dietary supplementation with alpha-tocopherol reduces neuroinflammation and neuronal degeneration in the rat brain after kainic acid-induced status epilepticus. Free Radic. Res. 2011, 45, 1136-1142. [CrossRef] [PubMed]

178. Zaja-Milatovic, S.; Gupta, R.C.; Aschner, M.; Montine, T.J.; Milatovic, D. Pharmacologic suppression of oxidative damage and dendritic degeneration following kainic acid-induced excitotoxicity in mouse cerebrum. Neurotoxicology 2008, 29, 621-627. [CrossRef] [PubMed]

179. Tome, A.R.; Feng, D.; Freitas, R.M. The effects of alpha-tocopherol on hippocampal oxidative stress prior to in pilocarpine-induced seizures. Neurochem. Res. 2010, 35, 580-587. [CrossRef] [PubMed]

180. Simeone, K.A.; Matthews, S.A.; Samson, K.K.; Simeone, T.A. Targeting deficiencies in mitochondrial respiratory complex I and functional uncoupling exerts anti-seizure effects in a genetic model of temporal lobe epilepsy and in a model of acute temporal lobe seizures. Exp. Neurol. 2014, 251, 84-90. [CrossRef]

181. NIH Office of Dietary Supplements. Vitamin B6. Fact Sheet for Health Professionals. Available online: https://ods.od.nih.gov/factsheets/VitaminB6-HealthProfessional/ (accessed on 17 September 2018).

182. Subar, A.F.; Krebs-Smith, S.M.; Cook, A.; Kahle, L.L. Dietary sources of nutrients among US adults, 1989 to 1991. J. Am. Diet. Assoc. 1998, 98, 537-547. [CrossRef]

183. Bowling, F.G. Pyridoxine supply in human development. Semin. Cell Dev. Biol. 2011, 22, 611-618. [CrossRef]

184. Di Salvo, M.L.; Contestabile, R.; Safo, M.K. Vitamin B(6) salvage enzymes: Mechanism, structure and regulation. Biochim. Biophys. Acta 2011, 1814, 1597-1608. [CrossRef]

185. Spector, R.; Greenwald, L.L. Transport and metabolism of vitamin B6 in rabbit brain and choroid plexus. J. Biol. Chem. 1978, 253, 2373-2379. [PubMed]

186. Fox, J.T.; Tullidge, G.M. Pyridoxine (Vitamin B6) in epilepsy; a clinical trial. Lancet 1946, 2, 345. [CrossRef] 
187. Livingston, S.; Jeng, M.H.; Petersen, D.C. Ineffectiveness of pyridoxine (Vitamin B6) in the treatment of epilepsy. Pediatrics 1955, 16, 250-251. [PubMed]

188. Heeley, A.F.; Piesowicz, A.T.; McCubbing, D.G. The biochemical and clinical effect of pyridoxine in children with brain disorders. Clin. Sci. 1968, 35, 381-389. [PubMed]

189. Plecko, B.; Stockler, S. Vitamin B6 dependent seizures. Can. J. Neurol. Sci. 2009, 36, 73-77.

190. Mills, P.B.; Surtees, R.A.; Champion, M.P.; Beesley, C.E.; Dalton, N.; Scambler, P.J.; Heales, S.J.; Briddon, A.; Scheimberg, I.; Hoffmann, G.F.; et al. Neonatal epileptic encephalopathy caused by mutations in the PNPO gene encoding pyridox(am)ine 5'-phosphate oxidase. Hum. Mol. Genet. 2005, 14, 1077-1086. [CrossRef] [PubMed]

191. Mills, P.B.; Camuzeaux, S.S.M.; Footitt, E.J.; Mills, K.A.; Gissen, P.; Fisher, L.; Das, K.B.; Varadkar, S.M.; Zuberi, S.; McWilliam, R.; et al. Epilepsy due to PNPO mutations: Genotype, environment and treatment affect presentation and outcome. Brain 2014, 137, 1350-1360. [CrossRef]

192. Moore, C.A.; Ward, J.C.; Rivas, M.L.; Magill, H.L.; Whyte, M.P. Infantile hypophosphatasia: Autosomal recessive transmission to two related sibships. Am. J. Med. Genet. 1990, 36, 15-22. [CrossRef]

193. Waymire, K.G.; Mahuren, J.D.; Jaje, J.M.; Guilarte, T.R.; Coburn, S.P.; MacGregor, G.R. Mice lacking tissue non-specific alkaline phosphatase die from seizures due to defective metabolism of vitamin B-6. Nat. Genet. 1995, 11, 45-51. [CrossRef] [PubMed]

194. Van Karnebeek, C.D.; Tiebout, S.A.; Niermeijer, J.; Poll-The, B.T.; Ghani, A.; Coughlin, C.R., 2nd; Van Hove, J.L.; Richter, J.W.; Christen, H.J.; Gallagher, R.; et al. Pyridoxine-Dependent Epilepsy: An Expanding Clinical Spectrum. Pediatr. Neurol. 2016, 59, 6-12. [CrossRef]

195. Pena, I.A.; Marques, L.A.; Laranjeira, A.B.; Yunes, J.A.; Eberlin, M.N.; MacKenzie, A.; Arruda, P. Mouse lysine catabolism to aminoadipate occurs primarily through the saccharopine pathway; implications for pyridoxine dependent epilepsy (PDE). Biochim. Biophys. Acta Mol. Basis Dis. 2017, 1863, 121-128. [CrossRef] [PubMed]

196. Jagadeesh, S.; Suresh, B.; Murugan, V.; Suresh, S.; Salomans, G.S.; Struys, E.A.; Jacobs, C. Pyridoxine-dependent epilepsy owing to antiquitin deficiency-Mutation in the ALDH7A1 gene. Paediatr. Int. Child Health 2013, 33, 113-115. [CrossRef] [PubMed]

197. Pena, I.A.; Roussel, Y.; Daniel, K.; Mongeon, K.; Johnstone, D.; Weinschutz Mendes, H.; Bosma, M.; Saxena, V.; Lepage, N.; Chakraborty, P.; et al. Pyridoxine-Dependent Epilepsy in Zebrafish Caused by Aldh7a1 Deficiency. Genetics 2017, 207, 1501-1518. [CrossRef] [PubMed]

198. NIH Office of Dietary Supplements. Vitamin C. Fact Sheet for Health Professionals. Available online: https://ods.od.nih.gov/factsheets/VitaminC-HealthProfessional/ (accessed on 18 September 2018).

199. Tome Ada, R.; Ferreira, P.M.; Freitas, R.M. Inhibitory action of antioxidants (ascorbic acid or alpha-tocopherol) on seizures and brain damage induced by pilocarpine in rats. Arq. Neuropsiquiatr. 2010, 68, 355-361. [CrossRef] [PubMed]

200. Harrison, F.E.; May, J.M. Vitamin C function in the brain: Vital role of the ascorbate transporter SVCT2. Free Radic. Biol. Med. 2009, 46, 719-730. [CrossRef] [PubMed]

201. Santos, I.M.; Tome Ada, R.; Saldanha, G.B.; Ferreira, P.M.; Militao, G.C.; Freitas, R.M. Oxidative stress in the hippocampus during experimental seizures can be ameliorated with the antioxidant ascorbic acid. Oxid. Med. Cell. Longev. 2009, 2, 214-221. [CrossRef] [PubMed]

202. Gonzalez-Ramirez, M.; Razo-Juarez, L.I.; Sauer-Ramirez, J.L.; Gonzalez-Trujano, M.E.; Salgado-Ceballos, H.; Orozco-Suarez, S. Anticonvulsive effect of vitamin C on pentylenetetrazol-induced seizures in immature rats. Pharmacol. Biochem. Behav. 2010, 97, 267-272. [CrossRef]

203. Schneider Oliveira, M.; Flavia Furian, A.; Freire Royes, L.F.; Rechia Fighera, M.; de Carvalho Myskiw, J.; Gindri Fiorenza, N.; Mello, C.F. Ascorbate modulates pentylenetetrazol-induced convulsions biphasically. Neuroscience 2004, 128, 721-728. [CrossRef]

204. Ayyildiz, M.; Coskun, S.; Yildirim, M.; Agar, E. The effects of ascorbic acid on penicillin-induced epileptiform activity in rats. Epilepsia 2007, 48, 1388-1395. [CrossRef]

205. Das, A.; Sarwar, M.S.; Hossain, M.S.; Karmakar, P.; Islam, M.S.; Hussain, M.E.; Banik, S. Elevated Serum Lipid Peroxidation and Reduced Vitamin C and Trace Element Concentrations Are Correlated With Epilepsy. Clin. EEG Neurosci. 2019, 50, 63-72. [CrossRef]

206. Desagher, S.; Glowinski, J.; Premont, J. Pyruvate protects neurons against hydrogen peroxide-induced toxicity. J. Neurosci. 1997, 17, 9060-9067. [CrossRef] [PubMed] 
207. Kao, K.K.; Fink, M.P. The biochemical basis for the anti-inflammatory and cytoprotective actions of ethyl pyruvate and related compounds. Biochem. Pharmacol. 2010, 80, 151-159. [CrossRef] [PubMed]

208. Popova, I.; Malkov, A.; Ivanov, A.I.; Samokhina, E.; Buldakova, S.; Gubkina, O.; Osypov, A.; Muhammadiev, R.S.; Zilberter, T.; Molchanov, M.; et al. Metabolic correction by pyruvate halts acquired epilepsy in multiple rodent models. Neurobiol. Dis. 2017, 106, 244-254. [CrossRef]

209. Brodie, M.J. Antiepileptic drug therapy the story so far. Seizure 2010, 19, 650-655. [CrossRef] [PubMed]

210. Botchway, B.O.A.; Moore, M.K.; Akinleye, F.O.; Iyer, I.C.; Fang, M. Nutrition: Review on the Possible Treatment for Alzheimer's Disease. J. Alzheimers Dis. 2018, 61, 867-883. [CrossRef] [PubMed]

211. Larsson, S.C. Dietary Approaches for Stroke Prevention. Stroke 2017, 48, 2905-2911. [CrossRef] [PubMed]

212. Hang, L.; Basil, A.H.; Lim, K.L. Nutraceuticals in Parkinson's Disease. Neuromolecular Med. 2016, 18, $306-321$. [CrossRef]

213. Szwajgier, D.; Borowiec, K.; Pustelniak, K. The Neuroprotective Effects of Phenolic Acids: Molecular Mechanism of Action. Nutrients 2017, 9, 477. [CrossRef]

214. Castro, O.W.; Upadhya, D.; Kodali, M.; Shetty, A.K. Resveratrol for Easing Status Epilepticus Induced Brain Injury, Inflammation, Epileptogenesis, and Cognitive and Memory Dysfunction-Are We There Yet? Front. Neurol. 2017, 8, 603. [CrossRef]

215. Ojemann, L.M.; Nelson, W.L.; Shin, D.S.; Rowe, A.O.; Buchanan, R.A. Tian ma, an ancient Chinese herb, offers new options for the treatment of epilepsy and other conditions. Epilepsy Behav. 2006, 8, 376-383. [CrossRef]

216. Kulkarni, S.K.; Dhir, A. Withania somnifera: An Indian ginseng. Prog. Neuropsychopharmacol. Biol. Psychiatry 2008, 32, 1093-1105. [CrossRef] [PubMed]

217. Vishnoi, S.; Raisuddin, S.; Parvez, S. Glutamate Excitotoxicity and Oxidative Stress in Epilepsy: Modulatory Role of Melatonin. J. Environ. Pathol. Toxicol. Oncol. 2016, 35, 365-374. [CrossRef] [PubMed]

218. Dalton, K.; Dalton, M.J. Characteristics of pyridoxine overdose neuropathy syndrome. Acta Neurol. Scand. 1987, 76, 8-11. [CrossRef] [PubMed]

(C) 2019 by the authors. Licensee MDPI, Basel, Switzerland. This article is an open access article distributed under the terms and conditions of the Creative Commons Attribution (CC BY) license (http://creativecommons.org/licenses/by/4.0/). 